\title{
Recent Investigations at the Mounds Plantation Site (16CD12), Caddo Parish, Louisiana
}

Jeffery S. Girard

Northwestern State University of Louisiana

Follow this and additional works at: https://scholarworks.sfasu.edu/ita

Part of the American Material Culture Commons, Archaeological Anthropology Commons, Environmental Studies Commons, Other American Studies Commons, Other Arts and Humanities Commons, Other History of Art, Architecture, and Archaeology Commons, and the United States History Commons

Tell us how this article helped you.

This Article is brought to you for free and open access by the Center for Regional Heritage Research at SFA ScholarWorks. It has been accepted for inclusion in Index of Texas Archaeology: Open Access Gray Literature from the Lone Star State by an authorized editor of SFA ScholarWorks. For more information, please contact cdsscholarworks@sfasu.edu. 


\section{Recent Investigations at the Mounds Plantation Site (16CD12), Caddo Parish, Louisiana}

\section{Creative Commons License}

\section{(c) (1) \&}

This work is licensed under a Creative Commons Attribution-NonCommercial 4.0 International License 


\section{RECENT INVESTIGATIONS AT THE Mounds Plantation Site (16CD12), CADDo PARISH, Louisiana}

\section{Jeffrey S. Girard}

\section{Introduction}

Dr. Montroville Wilson Dickeson, born in Philadelphia in 1810, was a medical doctor, taxidermist and avid collector of fossils. Between 1837 and 1844 he pursued another interest-excavating Indian burial mounds in the Ohio and Mississippi River valleys. He claimed to have "opened up" more than a thousand mounds and collected more than 40,000 objects. He also made drawings of the mounds and later provided these to an artist by the name of John J. Egan, who, about 1850, converted the drawings into a series of large paintings on huge canvases. Dickeson toured the country in 1852 allowing the public to view the canvasses and his artifact collections for a fee of 25 cents (Figure 1). The panorama, titled "Monumental Grandeur of the Mississippi Valley", was nine feet high, 400 feet long, and consisted of 27 scenes. The canvasses later were curated at the University Museum, University of Pennsylvania until 1953 when purchased by the St. Louis Art Museum where they remain today (Rathbone 1950; Rodgers 2009).

Dickeson's lecture notes refer to Scene 21 as follows: "The following picture shows a group of connected mounds in Caddo Parish, in Northwestern Louisiana, with some of the aboriginal inhabitants of the region ..." The scene depicts a cluster of nine mounds, some of which are connected by low earthen walls (Figure 2). In the background are mountains, and a group of Indians with elaborate headdresses are shown in front of tents. Similar mountains and the same Indian scene appear in other segments of the Mississippi Panorama and are understandable in light of the Romantic artistic style of the times, as well as the fact that the panorama was part of a show intended to evoke wonder and awe in its audience. Today we know of only one place in Caddo Parish where there is a cluster of at least nine mounds. Located on the western side of the Red River, north of the present city of Shreveport, is the Mounds Plantation Site (16CD12), the single largest Caddo ceremonial center in northwestern Louisiana (Figure 3). It seems fitting that the earliest reference that we have to a prehistoric site in northwest Louisiana likely pertains to Mounds Plantation, a place of primary importance to its ancient Caddo inhabitants, as well as to modern archaeological research.

Mounds Plantation is situated on natural levee deposits associated with a now abandoned Red River channel segment known as Moon Lake Bed (Figure 4). The main portion of the site is located southwest of a shallow channel scar that parallels Moon Lake Bed. However, some artifacts have been reported between the scar and lake. The highest portion of the natural levee lies adjacent to the shallow channel scar. This area contains the highest surface artifact densities and appears to have been a major locus of habitation. However, dense concentrations of pottery have been located beneath Mounds 3 and 6, and considerable material also was found beneath clay deposits adjacent to Mound 2 (see below). The clay probably resulted from deposition of fine-grained sediments when the site lay on the margin of a large floodplain lake known as T'Soto or Sodo Lake. T'Soto Lake apparently began to form in the late $18^{\text {th }}$ century due to the effects of the Red River Raft, and it reached its maximum size around 1840 . Veatch (1899) compiled $19^{\text {th }}$ century survey plat maps to show the overall extent of the lake in the early $19^{\text {th }}$ century (Figure 5). 


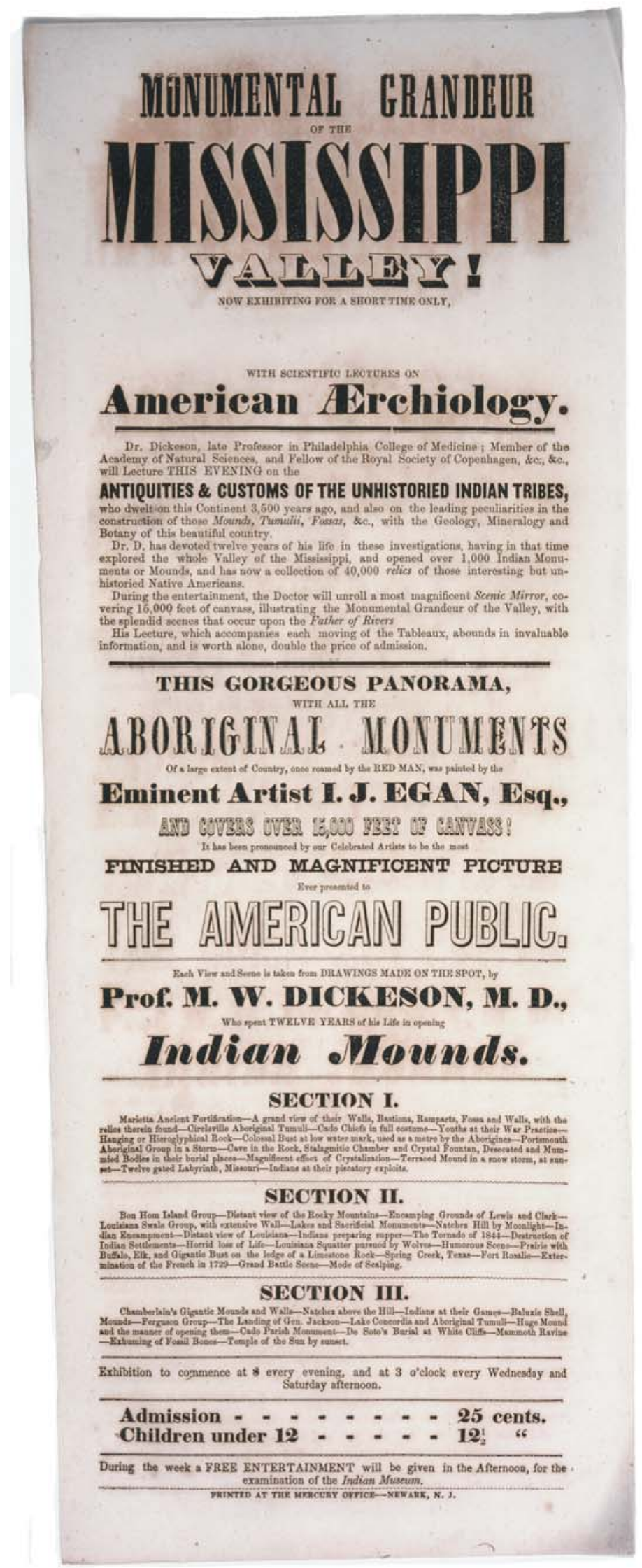

[John J. Egan, American (born Ireland), 1810-1882; Panorama of the Monumental Grandeur of the Mississippi Valley (handbill), c. 1850; Saint Louis Art Museum, Eliza McMillan Trust 34:1953]

Figure 1. Handbill for the exhibit, Panorama of the Monumental Grandeur of the Mississippi Valley. 


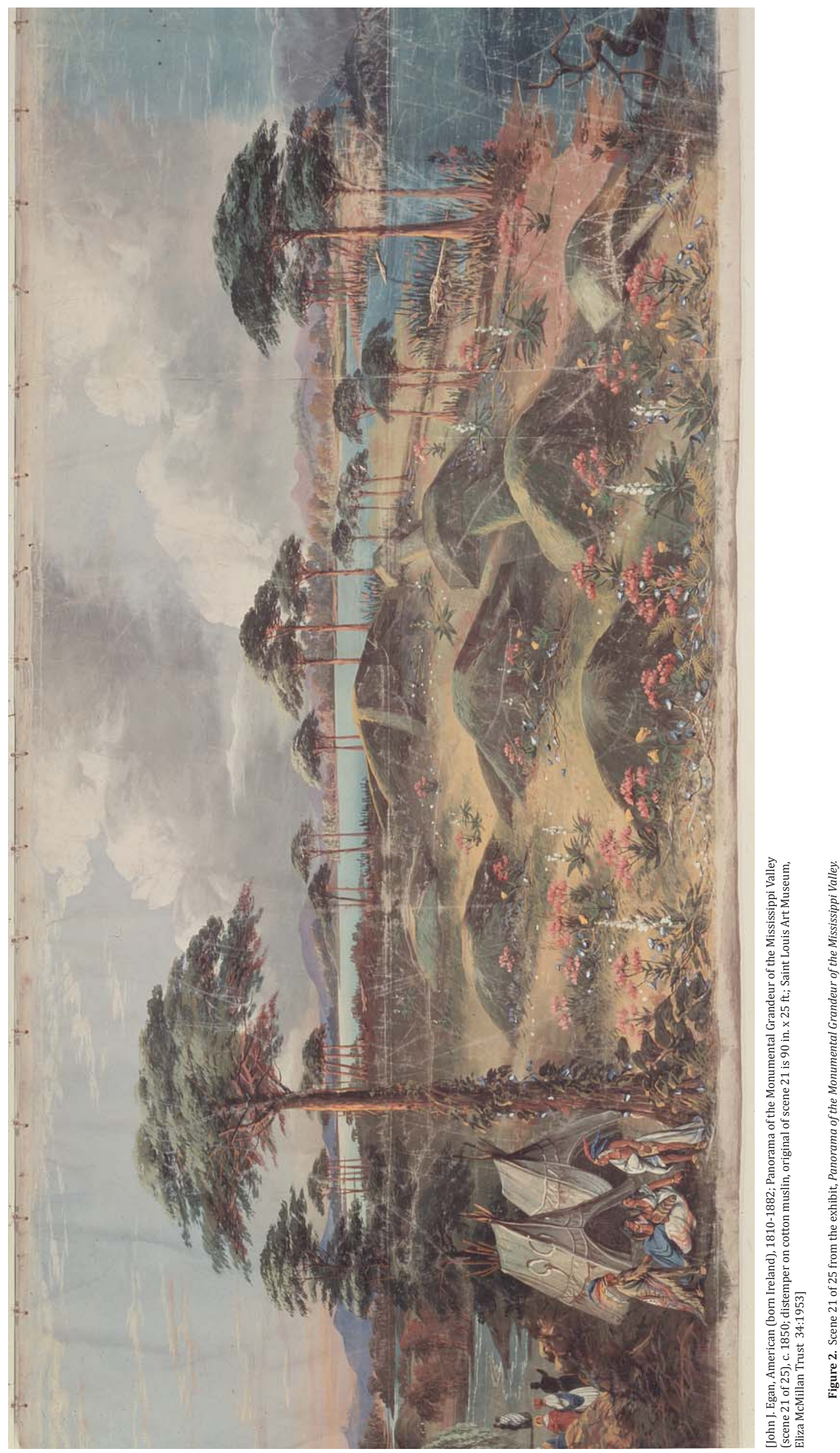


24 - Volume 22, 2012 


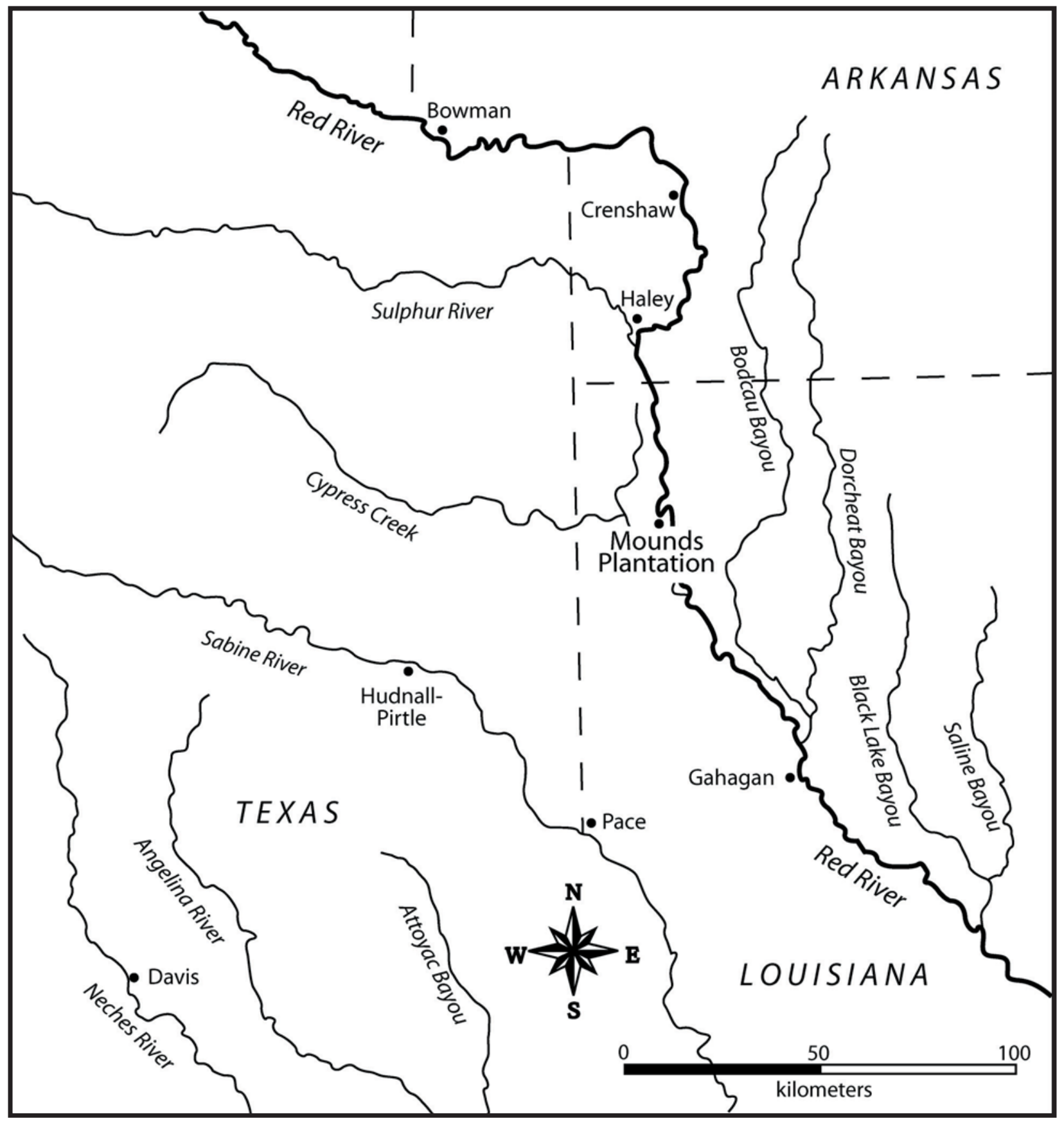

Figure 3. Location of the Mounds Plantation Site and selected other Early Caddo period mound sites. 


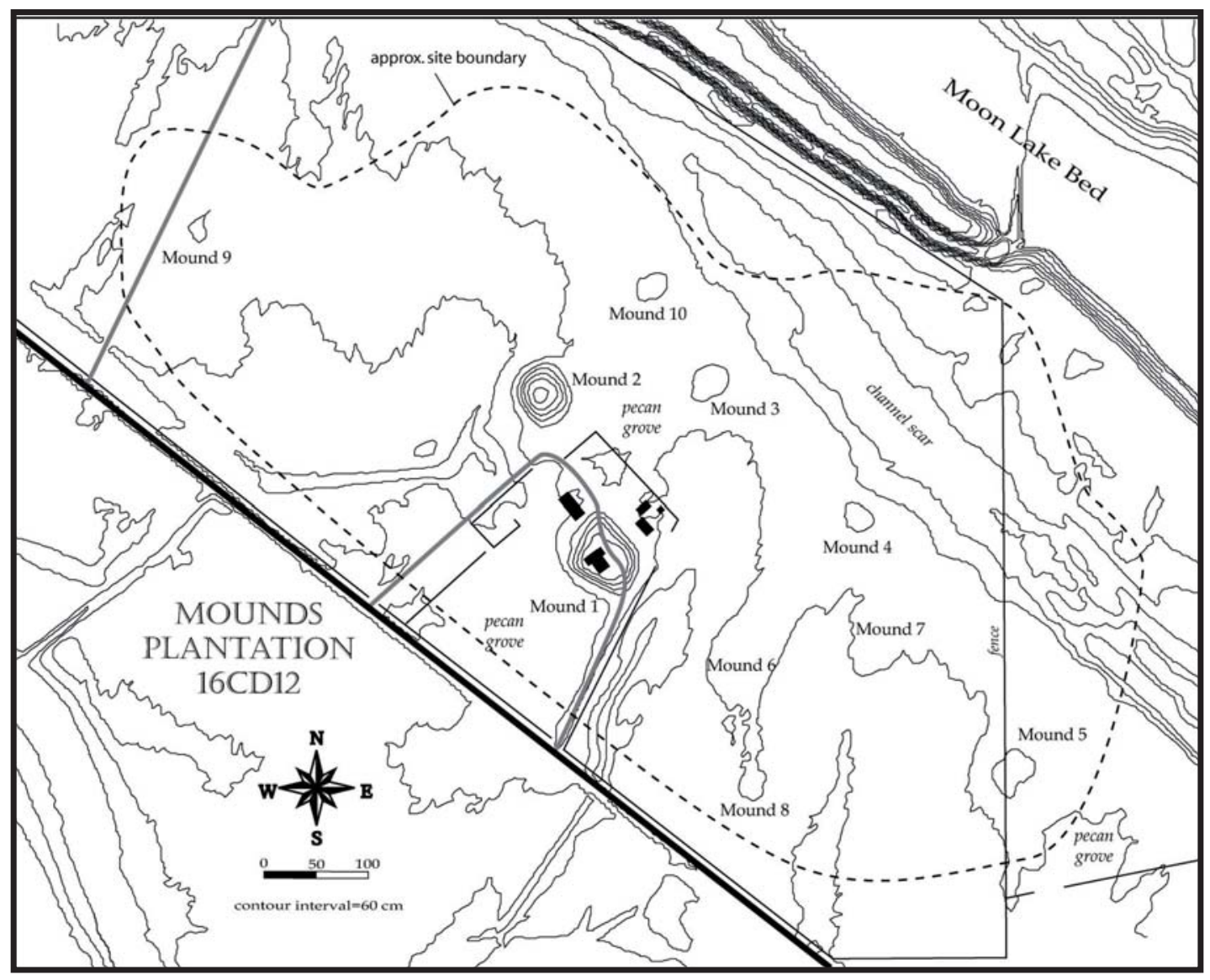

Figure 4. Map of the Mounds Plantation Site. LIDAR contour data distributed by "Atlas: The Louisiana Statewide GIS.” LSU CADGIS Research Laboratory, Baton Rouge, LA, 2006, http://atlas.lsu.edu.

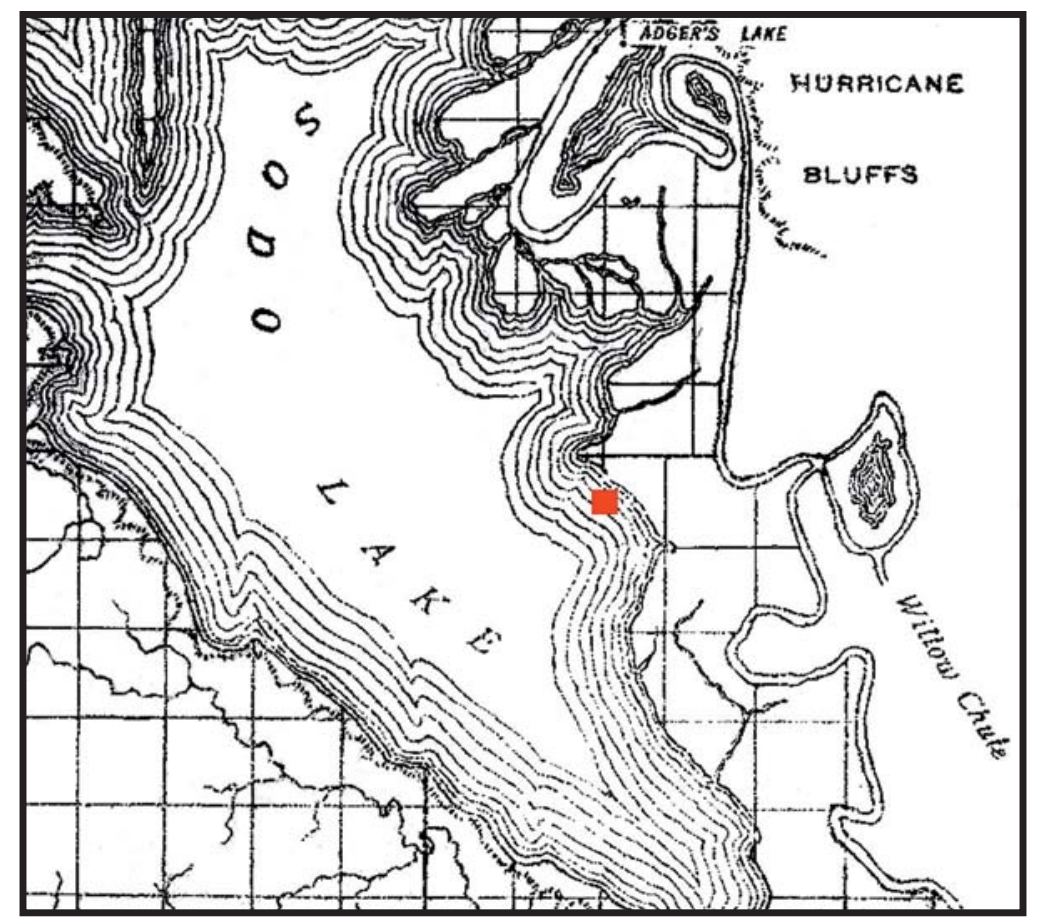

Figure 5. Detail of Red River floodplain map in Veatch (1899) showing location of the Mounds Plantation Site in relation to historic Sodo Lake. 
Dickeson apparently visited Mounds Plantation not long after Henry Shreve initially cleared portions of the raft between 1833 and 1838. Rafting continued upstream from Shreve's projects, however, and steamboats were able to navigate through the lake until it was drained following the work of Lt. Woodruff in 1873 (Veatch 1899:164-167; Triska 2008).

More than 50 years after Dickeson's visit, geologist Arthur Veatch (1899) made the following notes about the site:

Group of three mounds. They are rudely rectangular, truncated pyramid mounds. The largest is known as "Treasure mound." It is almost square, measuring about 75 feet each way, and is about 16 feet high. It is composed of black, sandy loam like that beneath the veneer of red clay on the surrounding land. An excavation about six feet square has been made on the eastern side and a pot is reported to have been discovered. A small excavation was started on the west side but was abandoned before anything was discovered. About 150 feet south of the mound is a "water-hole." This probably represents the excavation from which the material was obtained for the mound. The top of the mound is covered with a growth of white locust and is said to the only place in the region where it is found. The mound although surrounded by the waters of Sodo Lake during the raft period, was not covered. It was used as a place of refuge during the war by persons desirous of escaping the conscription officers.

"Arick's mound," the second of the series, is rudely rectangular, measuring 40 by 50 feet on top, and is 12 feet high.

"Youngblood mound" is 6 feet high and about the same dimensions on top as "Arick's mound."

A fourth elevation, known as "Trezevent mound," is found in the same group. It is very irregular and appears to be simply a natural elevation (Veatch 1899: 210-202).

In 1912, Mounds Plantation was visited by C.B. Moore on his Red River expedition (Moore 1912; Weinstein et al. 2003). At that time it was located on the plantation of Mr. H.L. Heilperin of Shreveport and Moore referred to the site as "Pickett's Landing." Moore noted the presence of seven mounds along with several insignificant rises and small ponds representing borrow areas. The mounds formed an irregular ellipse. Two (probably those later designated by Clarence Webb as Mounds 2 and 5) faced one another at a distance of 615 yards. Two other mounds were located south of the ellipse (probably Mounds 1 and 6), and the remaining three (Mounds 3, 4, and 7) were situated to the north. Moore noted that all of the mounds probably were quadrilateral, but two were too badly eroded to determine their shapes.

In 1912, atop all but one of the mounds was a house preventing extensive excavations. However, Moore excavated "numerous trial holes" in the two largest mound summits (apparently Mounds 1 and 2), as well as in two smaller mounds. He found nothing that he considered significant except that " . . on all four of which dark soil indicated former aboriginal abode." Artifacts, except for a few sherds, were scarce at the site but Moore believed (correctly) that most evidence was buried (Moore 1912:524-525).

Gerard Fowke of the Smithsonian Institution provided the next description of the site and was the first to use the name "Mounds Plantation" in print:

A group of these [flat-topped mounds], seven in number, 10 miles north of Shreveport, gives the name of "Mounds Plantation" to the estate on which they stand. Six of them have farm buildings on them, the seventh being cultivated as a garden or truck patch. It is unknown how far below the present surface their foundations may be; the ground has filled in several feet since the country was settled. This sedimentation no longer takes place, as floods are now confined by levees (Fowke 1928:406-407). 
The site subsequently was visited several times by Clarence Webb. In notes probably dating to the 1930s, he described site as consisting of "Large mounds in crescent shape, 4 distinct mounds all surmounted by dwellings, 2 less distinct. Few pottery fragments in fields". He reported that significant portions of Mounds 1 and 2 were cut down during the 1950s. In about 1950, Webb excavated a pit within a large depression that apparently served as a borrow area for the mounds. The pit contained numerous sherds and was underlain by fired clay likely to be the remnants of a hearth. Webb noted that, since the borrow area appeared to cut into the pit, the pit likely pre-dated mound construction (Webb and McKinney 1975:44-45).

Webb also excavated a child's burial that had been partially impacted by plowing in 1952 . The burial was located on the slope about $15 \mathrm{~m}$ east of Mound 7. Sherds of an undecorated, grog-tempered vessel were found to the right of the cranium (Webb and McKinney 1975:45). Webb reconstructed the vessel which now is in the Williamson Museum collection at Northwestern State University (Figure 6).

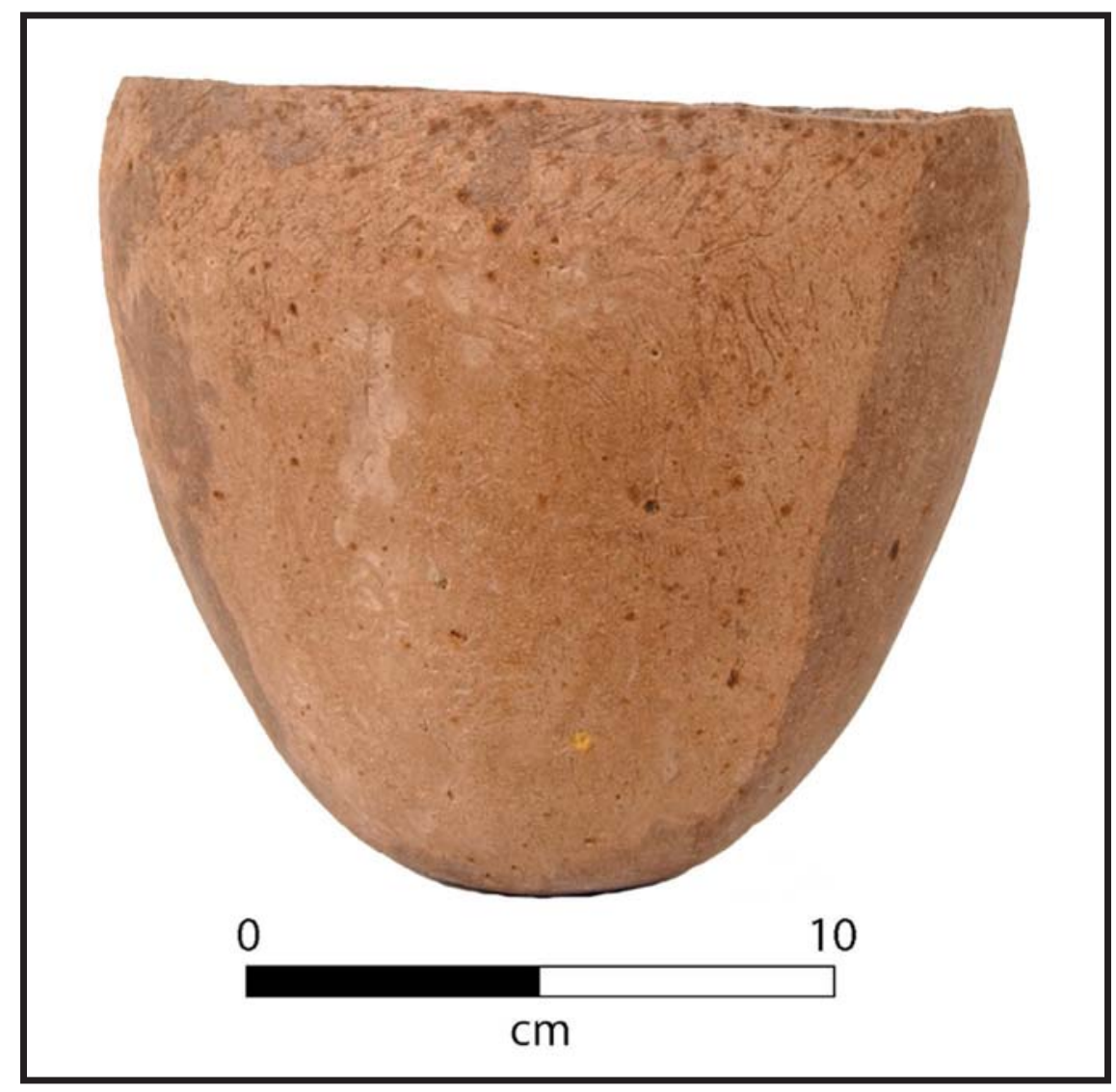

Figure 6. Undecorated deep bowl associated with child's burial.

Most of our present information about Mounds Plantation resulted from excavations conducted in 1959 and 1960 in Mounds 3 and 5 by Ralph McKinney with the assistance of Webb. Descriptions of these investigations, and the artifacts recovered from these mounds, are presented in Webb and McKinney (1975). Webb also made a map of the site based on aerial photographs and field observations. By that time, Webb had identified nine mounds, seven surrounding the plaza, and two (Mounds 8 and 9) on the periphery. Artifacts from Mound 5 have been loaned by the McKinney family to the Bossier History Center, Bossier Parish Library, in Bossier City, Louisiana. The McKinney Collection also appears to include some materials recovered from Mound 3, but these were stored in poorly labeled paper bags and proveniences are uncertain. 
In 1985 members of the Louisiana Archaeological Society led by Claude McCrocklin conducted a survey of the site and surrounding lands (McCrocklin 1985). The site had been plowed and cultivated for many years by this time and numerous artifacts were exposed on the surface. McCrocklin revised Webb's earlier map by plotting areas where artifacts appeared to be concentrated. He also identified two additional rises as probable mounds, bringing the site total to eleven.

Information acquired during mapping and test excavations conducted by Louisiana's Regional Archaeology Program based at Northwestern State University are the subject of this paper. In 2005, a detailed contour map was made of the site and several auger tests were placed along the terrace edge to determine the nature and depth of the remaining deposits (Girard 2005). The site was mapped to the fence that crosses Mound 5 on the eastern side of the site. A new landowner on the adjacent property granted us permission in January 2006 to extend the map and determine if any of Mound 5 remains on the eastern side of the fence. A 1-x-2-m test unit excavated into the northeastern edge of the mound remnant revealed that additional large pits likely remain beneath the low rise representing the former mound.

An archaeogeophysical survey, directed by Jami Lockhart of the Arkansas Archeological Survey was carried out in sample areas during 2007 (Lockhart and Girard 2007). The survey was conducted over a period of four days using three technologies. A total of $9,200 \mathrm{~m}^{2}$ was covered using gradiometry; 3,600 $\mathrm{m}^{2}$ with ground penetrating radar; and 2,800 $\mathrm{m}^{2}$ with electrical resistance. Of the four areas tested (Figure 7), Mounds 6 and 7 contained anomalies most similar to burned archeological features that have been ground-truthed in other agricultural settings, such as in the Mississippi River alluvial valley of Arkansas. Historic and modern disturbances and the introduction of metal near Mound 2 and the pecan grove resulted in these anomalies being less clear. Geophysical interpretation for these areas in particular would have benefited greatly from fullcoverage using electrical resistance, which is far less sensitive to the presence of metal. Electrical resistance data were collected, but spurious positive and negative data spikes in most of the data grids were more numerous than plausibly correct readings, so the data could not be salvaged. Test excavations were conducted adjacent to Mound 2 in 2008 and 2009 in areas where the geophysical data suggested possible features. In 2010 auger tests and one test pit were placed in Mound 6.

\section{Subsurface Investigations in the Mound 2 Area}

Mound 2 apparently was quadrilateral and flat topped in the early $20^{\text {th }}$ century and might be that referred to as Arick's Mound by Veatch (1899:202) who described it as 40 x $50 \mathrm{ft}$ (about 12x15 m) on the summit and $12 \mathrm{ft}(3.7 \mathrm{~m}$ ) tall. Moore's (1912) description of what probably is Mound 2 states that it was 70 $\mathrm{ft}$ (about $21 \mathrm{~m}$ ) in diameter on the summit with a base of $150 \mathrm{ft}(45.7 \mathrm{~m}$ ) in diameter (he did not estimate the height). The base of the mound now is much wider $(73 \times 60 \mathrm{~m}$ or about $240 \times 197 \mathrm{ft})$ but not as tall as described by Veatch (it now is $2.6 \mathrm{~m}$ or $8.5 \mathrm{ft}$. high). A tenant farm house that formerly stood on the mound summit was moved in the early 1960s. Webb reported that more than half of the mound was destroyed when the house was moved (Webb and McKinney 1975:43). It is more likely that about $1 \mathrm{~m}$ was removed and spread around the base of the mound, particularly on the southeastern side. The mound now is planted in grass and only minor erosion is visible.

The area immediately east of Mound 2 has not been plowed. Currently, grass covers the surface and a pecan grove is present farther to the east. Resistivity data obtained in 2007 showed numerous anomalies in this area, but none clearly related to prehistoric features. In 2008, two test units (Test Pit 1 and Test Pit 2) were excavated on the southeastern flank of the mound in areas where greater electrical resistance was indicated. A third unit was excavated in 2009 where soil probes showed that particularly dark buried deposits were present (Figure 8). 


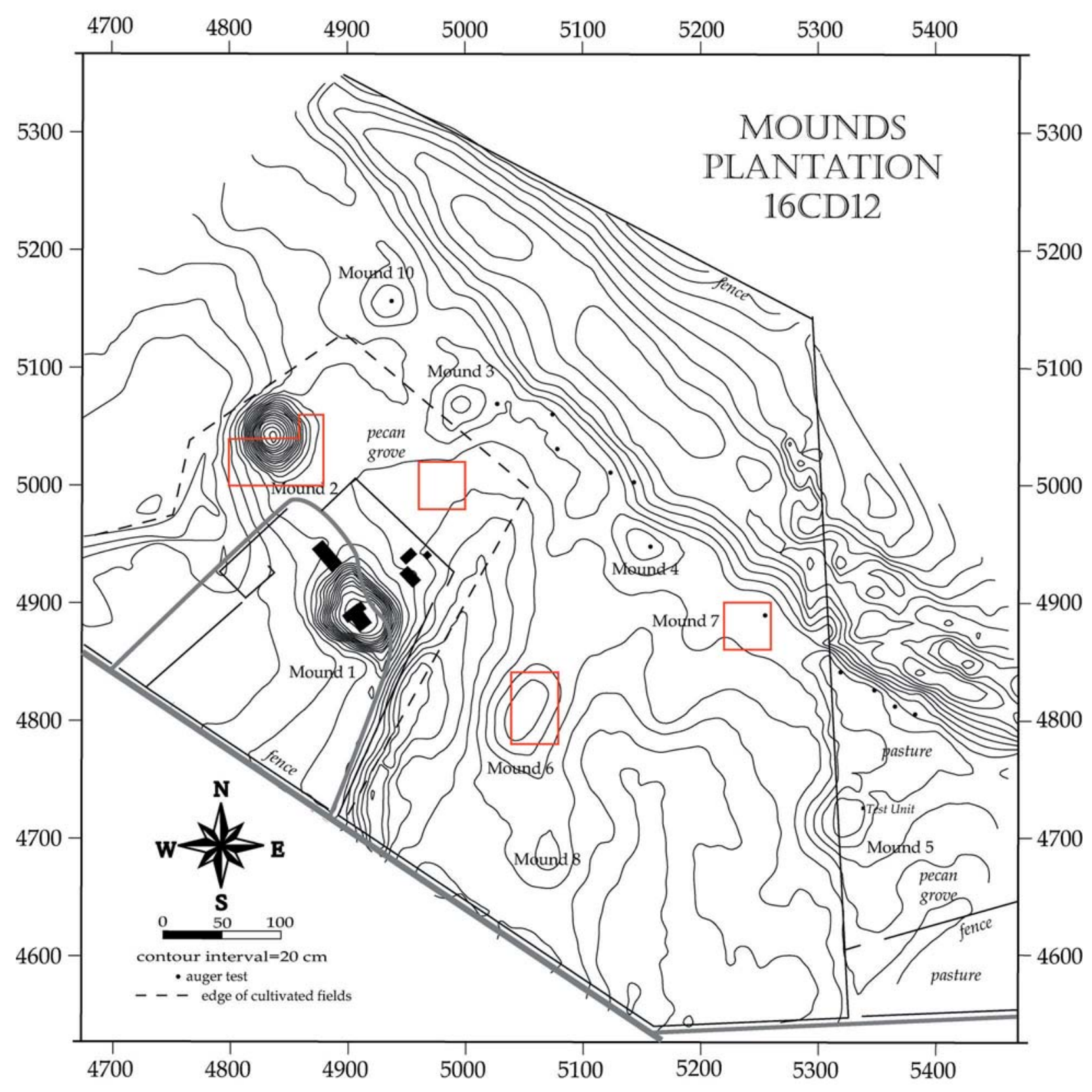

Figure 7. Sample areas for geophysical survey. 


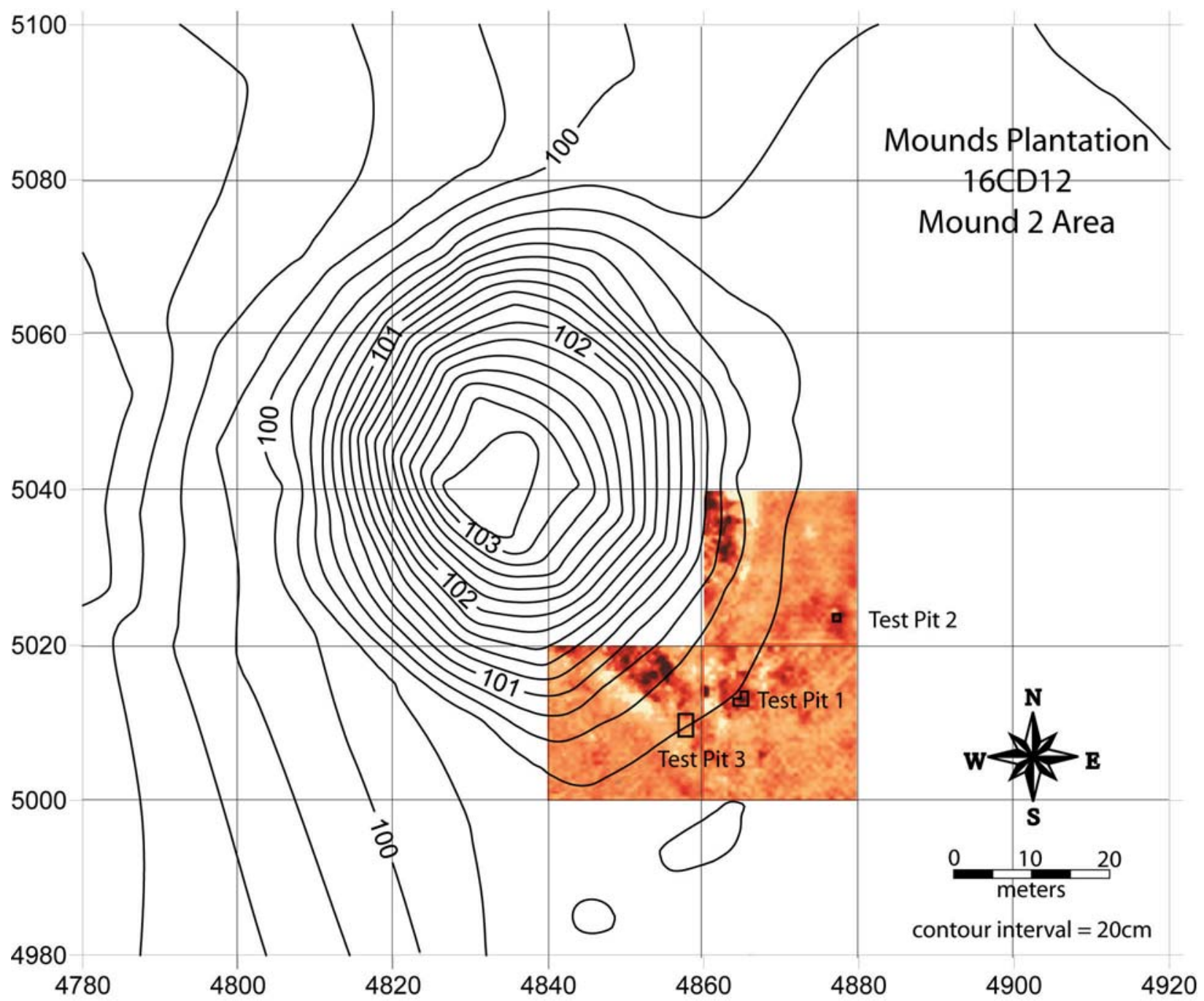

Figure 8. Locations of test units in the Mound 2 area with electrical resistance data.

Test Pit 1

Test Pit 1 was excavated in three 1-x-1-m units, each designated by its southwest corner gridpoint. The upper 15 to $20 \mathrm{~cm}$ consisted of dark reddish brown (5YR3/2 to 5YR3/3) very fine sandy loam, containing numerous historic artifacts, as well as a few chert flakes and Caddo sherds. The sediments and artifacts likely had washed or had been scraped off the top of the mound.

Underlying the upper deposits was a dark reddish brown (5YR3/4) clay stratum (C) devoid of artifacts (Figure 9). Clay covers large patches of the site, but is not uniformly present everywhere. A similar clay stratum was present at the base of Mound 5 (designated Stratum 1, see below) and was reported by Webb and McKinney (1975:50-51) directly overlying the submound midden in their Mound 5 excavations. They also noted discontinuous clay strata within the mound suggesting that the Caddos placed clay to serve as capping material as the mound was constructed. The submound clay stratum and that near Mound 2, however, likely is a natural lacustrine deposit related to the existence of T'Soto (or Sodo) Lake prior to clearing of the rafts in the Red River floodplain (see above). Veatch (1899:170) noted: "In the region of the Indian mounds ..., which was all under water during the raft period, there is a layer of stiff red clay from 6 inches to a foot thick overlying a black sandy clay similar to that on the Caddo prairie." The "black sandy clay" of the Caddo prairie probably is what now is classified as Armistead clay, but it is not clear why Veatch thought that this underlay the red clays in the Mounds Plantation area. 


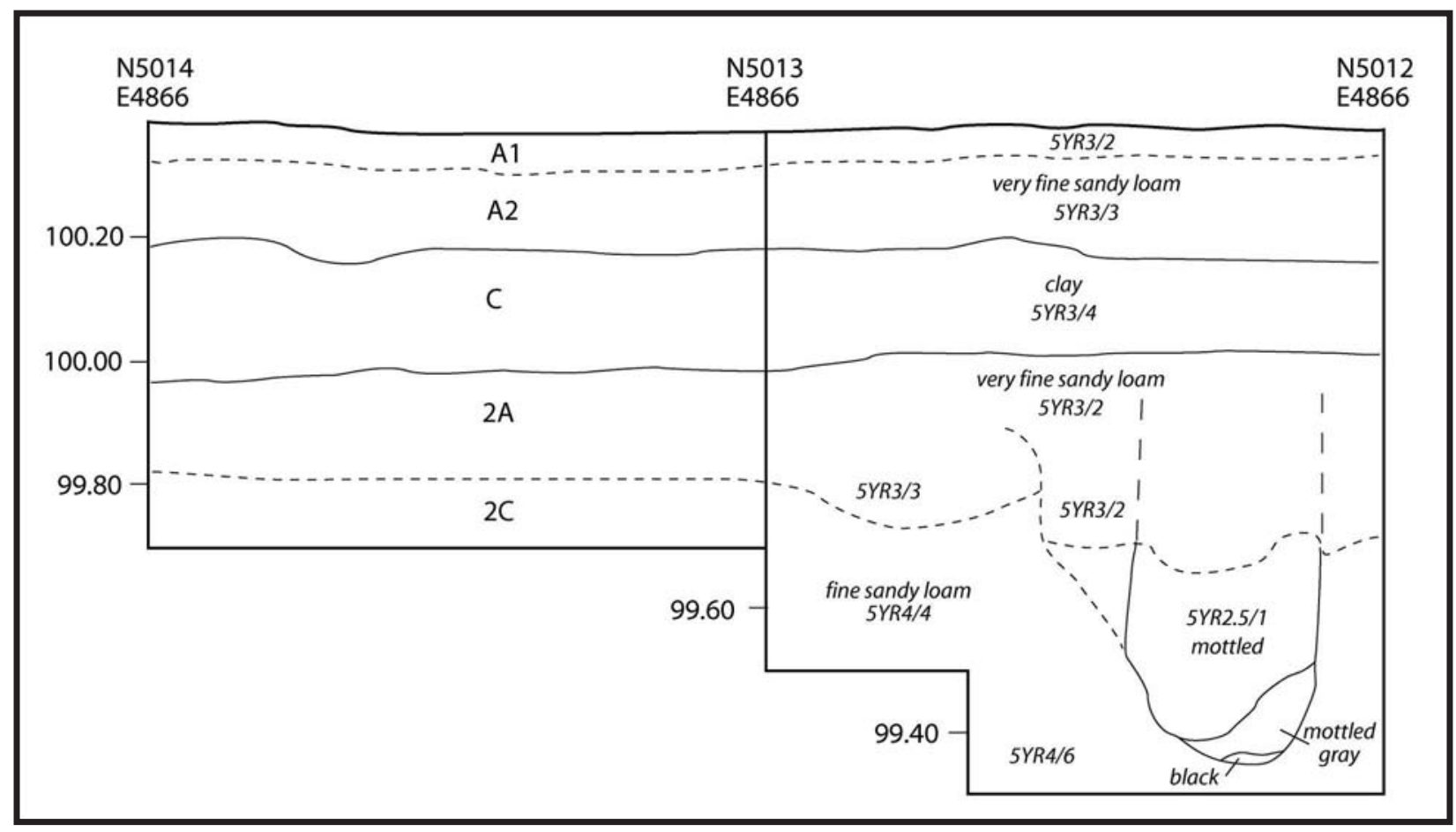

Figure 9. East profile of Test Pit 1, Mound 2 area, showing Feature 1.

Because excavation of the clay was extremely difficult and we felt that we had a sufficient sample of the historic artifacts, we only shovel excavated one of the three 1-x-1-m units (N5013E4865) in Test Pit 1. In the remaining two units (N5012E4865 and N5012E4864), we took off the upper strata (Levels 1-4, to 100.00 $\mathrm{m}$ ) with a backhoe. The landowner was able to do this without disturbing the underlying deposits or profiles (Figure 10).

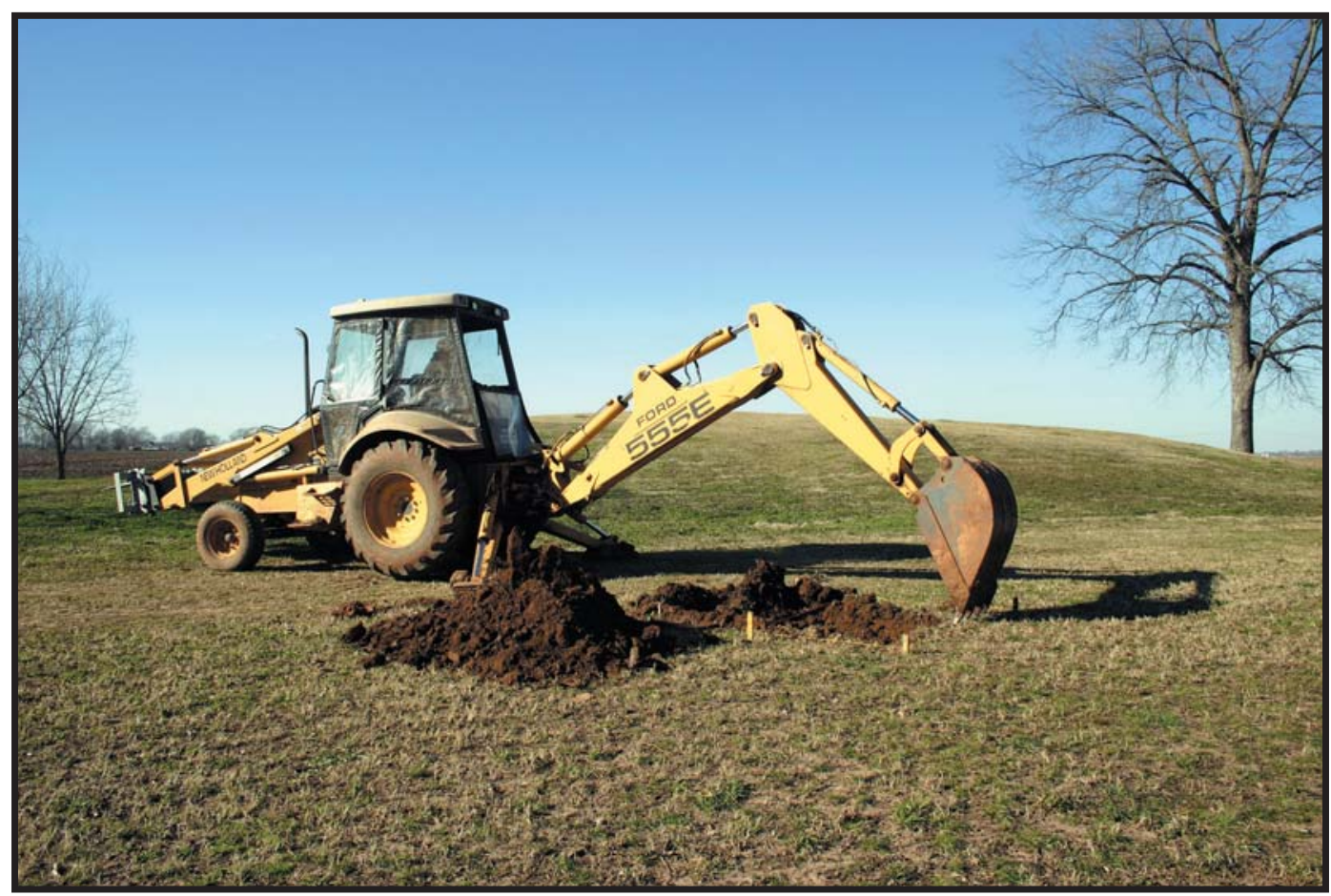

Figure 10. Removal of overburden using backhoe in the Mound 2 area. 
The clay stratum in the Mound 2 area was 15 to $20 \mathrm{~cm}$ thick and underlain by a dark reddish brown (5YR3/2 to 5YR3/3) very fine sandy loam, similar to the sediments overlying the clay stratum. This buried soil contained only prehistoric Caddo artifacts. The $2 \mathrm{~A}$ horizon was about $20 \mathrm{~cm}$ thick. The underlying $2 \mathrm{C}$ horizon was a reddish brown (5YR4/4) to yellowish red (5YR4/6) fine sandy loam. Artifacts diminished in numbers with depth and few were recovered by the base of Level 7 (99.70 m) except in the vicinity of Feature 2-1.

Dark deposits similar to the top of the 2A horizon remained in the southeast corner of unit N5012E4865 at the $99.70 \mathrm{~m}$ level (base of Level 7). Using a soil probe, we found that similar deposits extended at least an additional $30 \mathrm{~cm}$ and contained numerous flecks of charcoal. We continued excavation of the unit and at 99.65 $\mathrm{m}$, a well-defined semi-circular outline truncated by the east wall of the unit was visible and designated Feature 1. The feature appeared to represent a posthole similar to that found frequently in other Caddo sites. The fill was dark reddish brown (5YR3/2) with darker (5YR2.5/1) patches throughout. We continued excavation of the entire unit down to $99.50 \mathrm{~m}$, and then took a $40-\mathrm{x}-50 \mathrm{~cm}$ area down to 99.30 to expose the base of the feature in profile. No artifacts were recovered in the surrounding 2C horizon below the base of Level 8 (99.60 $\mathrm{m})$. The darkest portions began at the base of the 2A horizon (Figure 11). The diameter of Feature 1 was about $25 \mathrm{~cm}$ when detected. It tapered slightly with depth and the base appeared to be at $99.35 \mathrm{~m}$. Some leaching of charcoal was apparent causing mottling directly beneath. At the base of the 2A horizon, the feature deposits were black and contained numerous flecks of charcoal. This dark area might be the charred and decayed remains of an actual post and not just the posthole. In the profile, it was possible to trace the feature almost to the top of the $2 \mathrm{~A}$ horizon, although the color difference between the feature fill and $2 \mathrm{~A}$ horizon was subtle. The feature almost certainly originated from the former surface at the top of the $2 \mathrm{~A}$ horizon and did not go through the clay, ruling out the possibility that it was a historic fence post. A sample of the charcoal filled sediment from the lower portion of the feature was submitted for radiocarbon analysis and yielded an age of $930 \pm 25$ B.P. (UGA3264; wood charcoal; $\delta=-27.1$ ) [cal A.D. 1030-1160, 2-sigma].

\section{Test Pit 2}

Test Pit 2 consisted of a single 1-x-1-m unit with the southwest corner at N5023E4877 (see Figure 8). The clay extended to the surface in this area and no historic artifacts were recovered although a few small chunks of brick rubble were noted near the surface. The top of the buried soil (2A horizon) was encountered at about the same elevation $(100.00 \mathrm{~m})$ as found in Test Pit 1 , and was similar in color and texture. Very few artifacts were recovered, and no cultural features were detected.

Test Pit 3

To investigate this area further, we used a soil probe to explore variation in the buried A deposits in the vicinity of Test Pit 1. A particularly dark area was identified to the southwest and, in January 2009, we laid out a 2-x-2-m grid consisting of units N5008E4857, N5008E4858, N5009E4857, and N5009E4858 (Test Pit 3). We later expanded the test pit to the north by excavating units N5010E4857 and N5010E4858.

After placing stakes at the corners of the original 2-x-2-m area, the landowner removed the upper deposits (the upper A horizon and clay stratum) with a backhoe. The ground surface was at a site grid elevation of approximately $100.40 \mathrm{~m}$ in this area. We leveled the base of the backhoe excavation at $99.90 \mathrm{~m}$, approximately the contact of the clay with the underlying buried A horizon. Deposits in the buried A horizon were very dark gray (5YR3/1) to dark reddish brown (5YR3/2) loam that became gradually lighter in color (5YR3/3 to 5YR3/4) and slightly coarser (very fine sandy loam) with depth (Figure 12). Upon exposure, the deposits quickly dried out making excavation difficult, and a pick had to be used to loosen and break up the sediments. All fill was dry screened through $1 / 4$ " mesh. Artifact density was low to moderate to about the 99.60 $\mathrm{m}$ level, beneath which only a few specimens were recovered. Deposits below $99.60 \mathrm{~m}$ consisted of brown (7.5YR4/4) very fine sandy loam. Excavations were stopped at $99.60 \mathrm{~m}$ in the two southern units, but were taken down to $99.40 \mathrm{~m}$ to the north. 


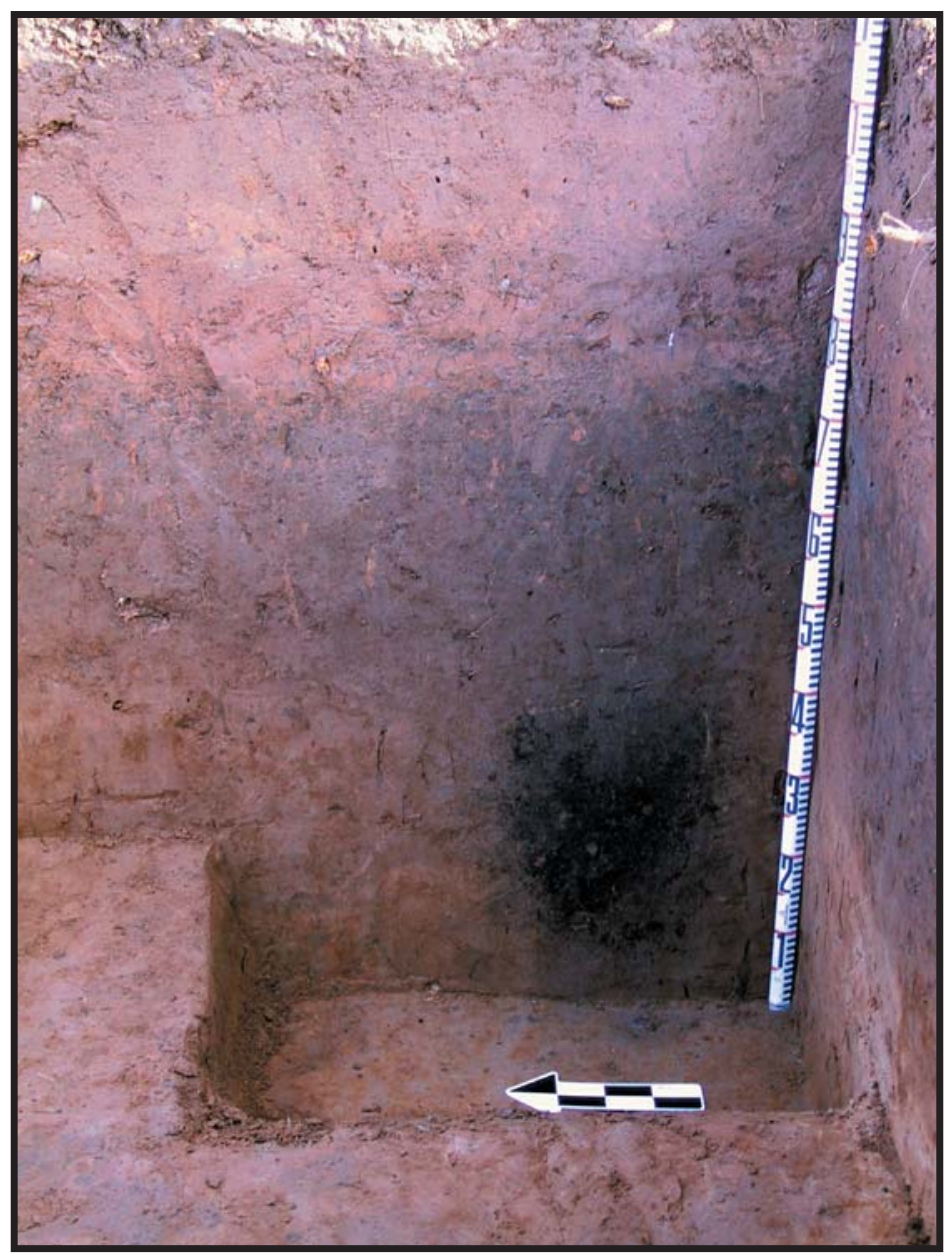

Figure 11. Feature 1 in southeast corner of Test Pit 1, Mound 2 area.
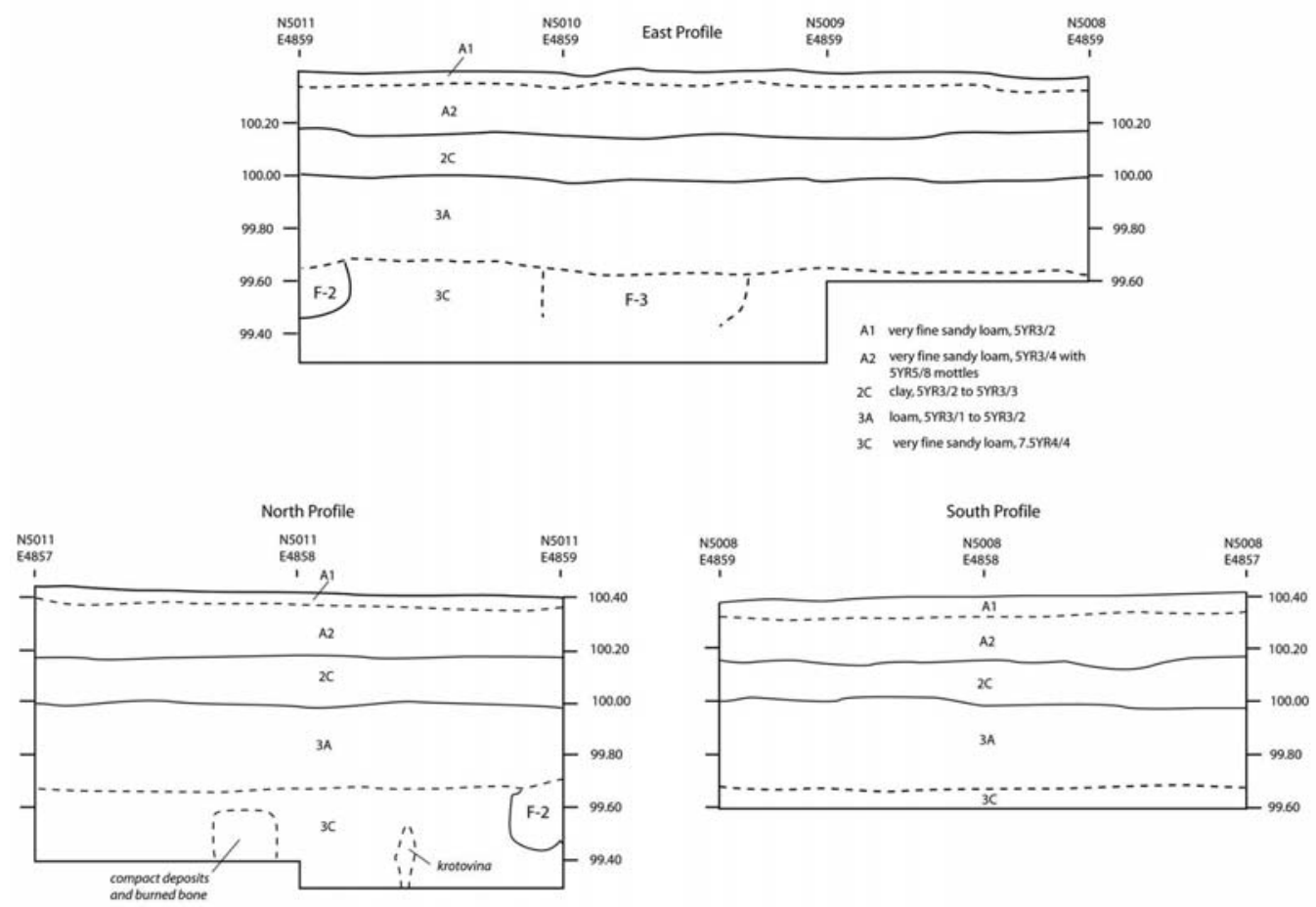

Figure 12. Profiles of Test Pit 3, Mound 2 area. 
In the northeast corner of Unit N5010E4858, a dark area was noted at the $99.70 \mathrm{~m}$ level. This became distinct by $99.65 \mathrm{~m}$ and was designated Feature 2. By $99.60 \mathrm{~m}$, the darkest portion of the feature appeared roughly circular although it extended beyond the unit into the north and east profiles (Figure 13). A more diffuse, lighter colored area extended to the west. Although the margins of the feature were distinct, the boundary with the surrounding deposits was not sharp. The fill contained small flecks of charcoal, but we did not recover a sufficient amount for radiocarbon dating. No artifacts or faunal remains were recovered in the fill. Feature 2 extended to approximately $99.42 \mathrm{~m}$ and had a well-defined, rounded base. The fill was darkest near the base, and could not be traced through the $2 \mathrm{~A}$ horizon. It is possible that the dark deposits resulted from the former presence of a post with a charred base that had been removed during the Caddo occupation. There was no evidence of in situ burning, nor did it appear that the post had rotted in place. Feature 1 also appeared to represent a former post charred only at the base-possibly a deliberate technique employed by the Caddos to retard post rotting. It should be noted, however, that the interpretation of this feature as a posthole is based on the exposed portion and the total extent is not known.

The 3C horizon consisted of a mottled fine sandy loam with different shades of brown (7.5YR4/4 and 7.5YR5/3) present in approximately equal degrees. Of a slightly different color (5YR4/4 dominant with mottled 5YR5/4) was a linear swatch that extended along a southeast to northwest axis through units N5009E4858, N5010E4858, and into N5010E4857 where it became difficult to discern (Figure 14). It was first apparent at the $99.60 \mathrm{~m}$ level, and continued to be well defined at the $99.40 \mathrm{~m}$ level. By $99.30 \mathrm{~m}$, however, it could no longer be detected. The lateral margins of the feature (designated Feature 3) were distinct, but neither the top nor the base was visible in the east profile of the test pit. Sediments did not differ in texture from the surrounding fine sandy loam of the $3 \mathrm{C}$ horizon - the feature was definable only on the basis of color. I think it unlikely that Feature 3 represents a pit or trench. It probably resulted from variation in permeability and compaction of the sediments due to the presence of a historic road that led to the tenant farm house on the top of the mound. Electrical resistance data clearly showed the former road in the vicinity of Test Pit 3 extending along a similar axis to the feature (see Figure 8).

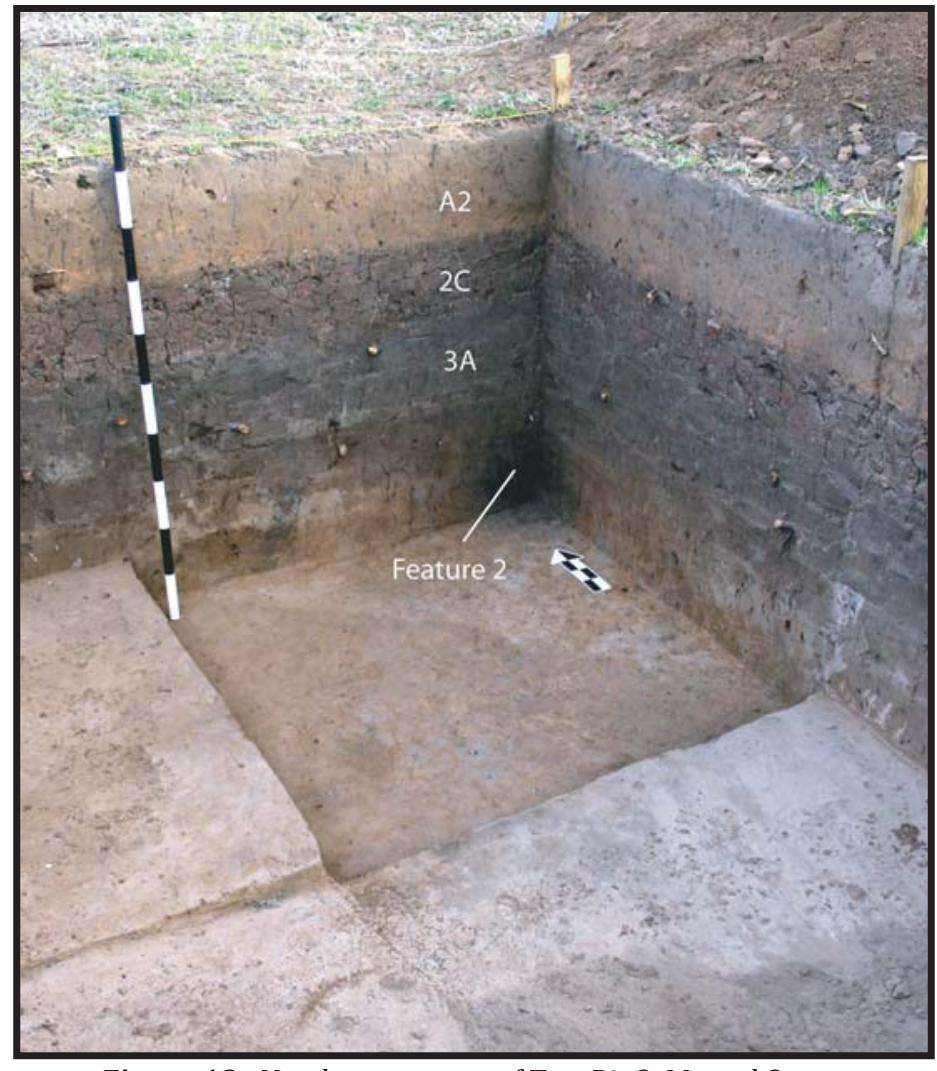

Figure 13. Northeast corner of Test Pit 3, Mound 2 area. 


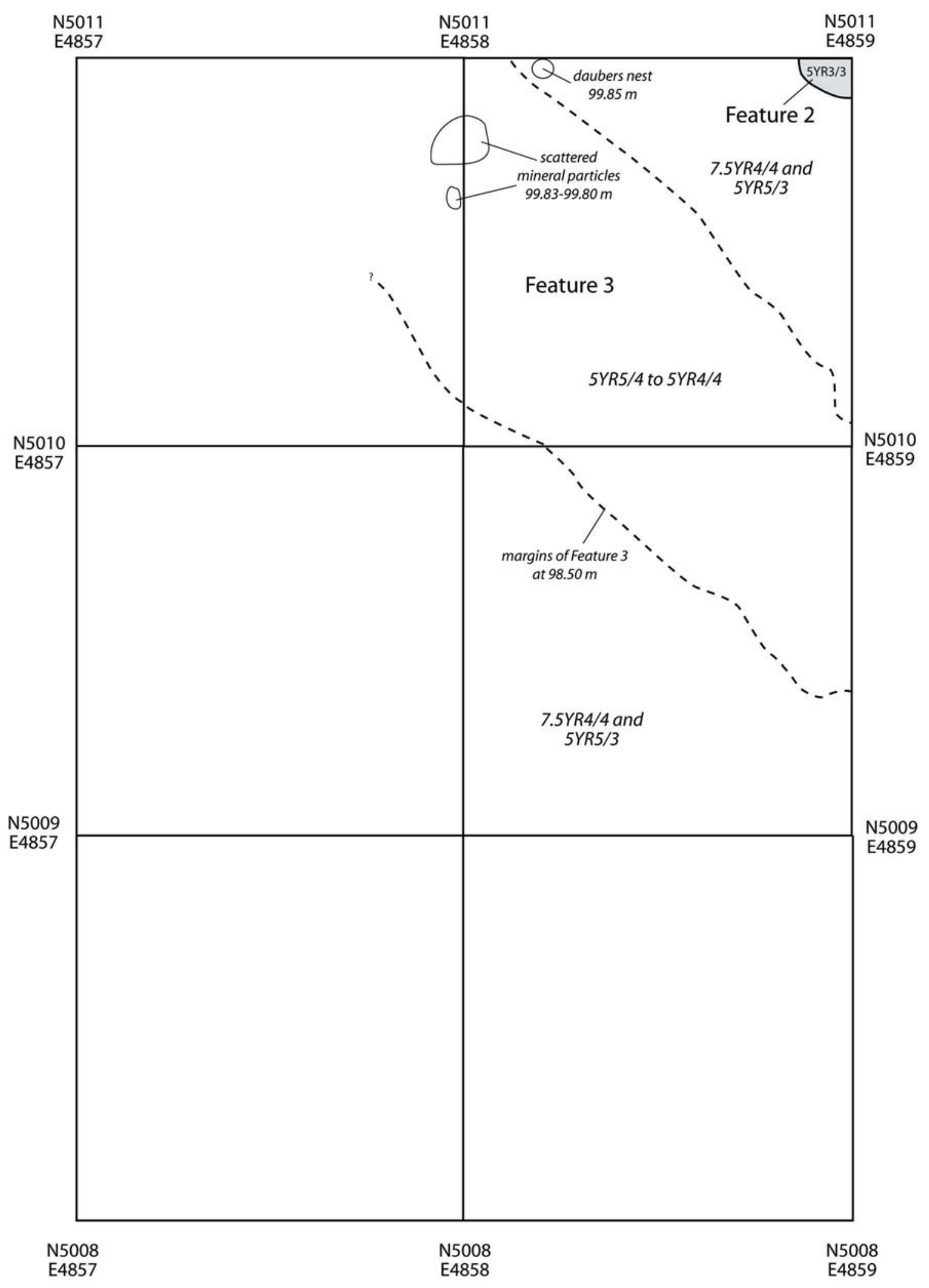

Figure 14. Base of Level 5 (99.50 m), Test Pit 3, Mound 2 area. 
Discussion

A few traits suggest that one or more prehistoric structures once existed in the vicinity of Test Pits 1 and 3, but additional excavations are necessary before this can be determined with certainty. Both Features 1 and 2 appear to represent postholes. They are approximately $7 \mathrm{~m}$ apart and are roughly similar in size and depth, and it is possible that they relate to a single structure. Both features were charred at their bases, but other evidence of in situ burning is missing other than widely scattered flecks of charcoal found throughout the 2A deposits. Burned lumps of clay, possibly structurally related, were found in low numbers in Test Pits 1 and 3 , except the southern portion of Test Pit 3. A few of these lumps have possible impressions of grass or cane thatch, but most specimens are too small to determine this with certainty. The highest amount by weight was in N5010E4857 of Test Pit 3. Another clue regarding the possible presence of a former structure in the area was a mud daubers nest recovered in the north profile of N5010E4858 at an elevation of $99.85 \mathrm{~m}$. The nest was made of grayish-green silty clay. At a slightly deeper elevation (between 99.83 and $99.80 \mathrm{~m}$ ) along the E4858 line, we encountered scattered lumps of mineral matter that have a glassy, siliceous appearance when magnified 10x or more using a binocular microscope. The nature of these particles is uncertain, but they may be examples of silica froth, possibly relating to burned thatch architecture (e.g., Jurney and Bergstrom 2001).

Artifact counts recovered from Test Pit 3 were comparable to those from Test Pit 1 (Figure 15). Sherd counts were highest in the northern units of Test Pit 3. Counts were more than twice as high in N5010E4857 and N5010E4858 as they were in the four units to the south. However, counts were almost as high in the eastern units of Test Pit 1 . Stone artifacts, mostly small flakes, were scattered in relatively similar numbers throughout both test pits. Small fragments of burned bone were recovered in all of the Test Pit 3 units, but none were found in Test Pit 1. With the present sample, it is not possible to delimit a distinct "midden" or trash dumping area.
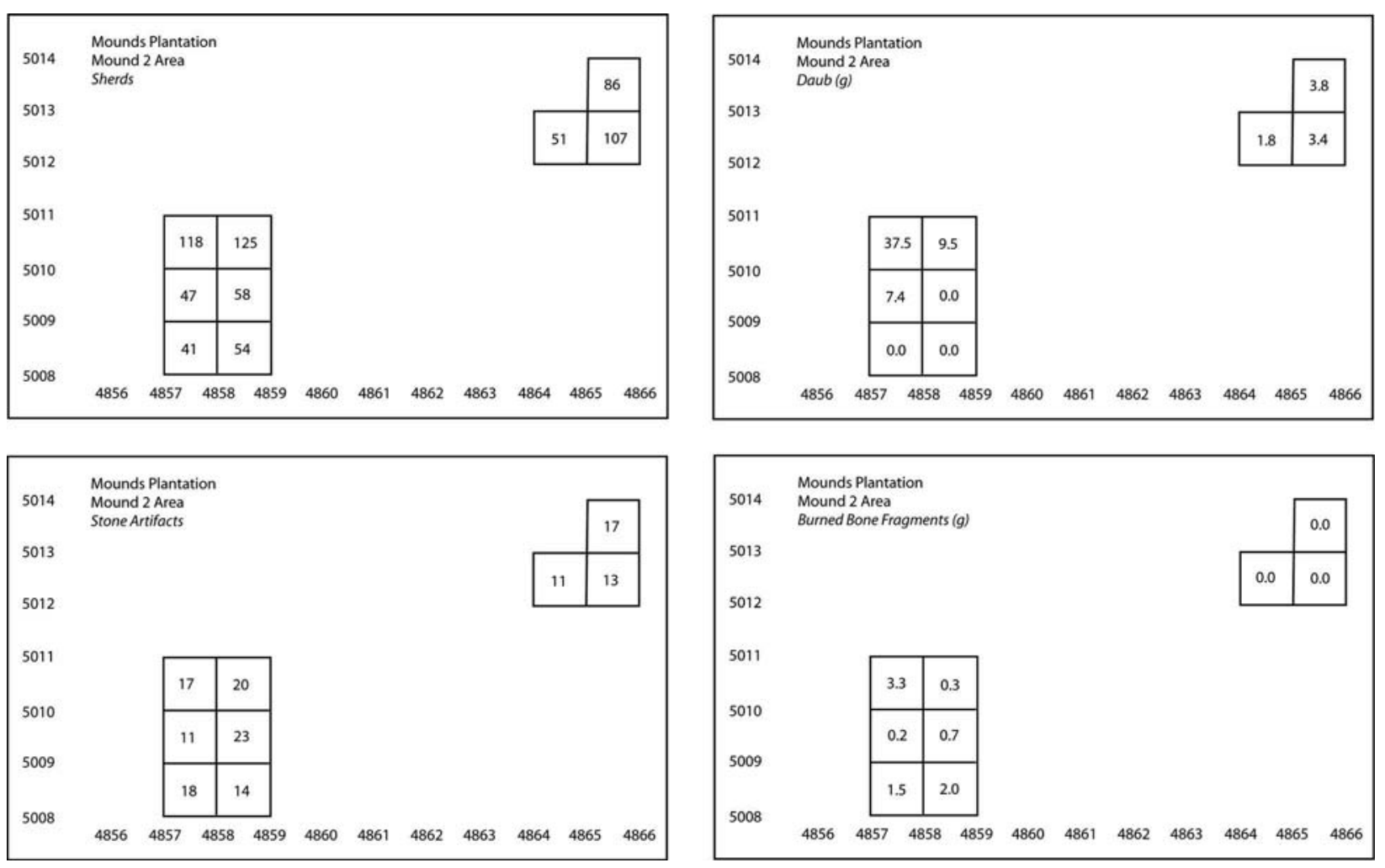

Figure 15. Schematic views of Test Pits 1 and 3 showing artifact distributions, Mound 2 area. 


\section{Ceramic Artifacts}

A total of 691 sherds greater than $1.5 \mathrm{~cm}$ were recovered from the Mound 2 area. Of these, $636(92.0 \%)$ are undecorated (Table 1). By far the most frequent decorative elements represented in the collection are horizontal incised lines, almost all of which appear to be applied to the neck or rim of the vessel. Sixteen of the 41 horizontal incised sherds have only a single line, either because only one line was present on the vessel or because multiple lines were spaced widely apart (Figure $16 \mathrm{~A}-\mathrm{G}$ ). One specimen (Figure $16 \mathrm{G}$ ) has short diagonal slashes below the horizontal line. All of the single line specimens were recovered from Test Pit 3 . Both Test Pits 1 and 3 contained several multiple horizontal line sherds (Figure $16 \mathrm{H}-\mathrm{V}$ ) and probably relate to the type Coles Creek Incised. I did not attempt to differentiate varieties for this sample, but a few specimens with relatively wide spacing might relate to vars. Greenhouse or Blakely (Figure 16 O-Q, T-V); and the closer-spaced specimens to var. Hardy (Figure $16 \mathrm{~J}-\mathrm{N}, \mathrm{R}-\mathrm{S}$ ). Multiple horizontal line incising also occurs on several types with punctated, incised, or brushed bodies, but the absence of body sherds with these decorations suggests that those types are not represented in this sample. Four sherds, three from Test Pit 3 and one from Test Pit 1, have triangular punctations underlying one or more horizontal incised line (Figure $16 \mathrm{~W}-\mathrm{Z}$ ). These specimens are classified as Coles Creek Incised, var. Coles Creek. However, on one specimen (Figure $16 \mathrm{Z}$ ), the punctation is arc-shaped and the specimen could be classified as Weches Fingernail Punctated. One Hollyknowe Pinched sherd (Figure $16 \mathrm{AA}$ ) was recovered. Curvilinear incising is present only on two specimens, one from Test Pit 1 and one from Test Pit 3 (Figure 16 BB,CC). Both specimens probably are from vessels of the type Crockett Curvilinear Incised. Engraving is present on four specimens, all from Test Pit 3 (Figure 16 DD-GG). On three, only horizontal lines are present. White pigment is present in the lines on one sherd (Figure $16 \mathrm{FF}$ ). The fourth engraved sherd (Figure $16 \mathrm{GG}$ ) has a curvilinear element and possibly relates to the type Glassell Engraved. This sherd, along with three sherds (not illustrated) of the type Belcher Ridged are considered diagnostic of the Middle and Late Caddo periods. Note that the midden from the sampled area near Mound 2 was not covered by moundfill and it appears that a few later specimens were incorporated into the deposits.

\begin{tabular}{|c|c|c|c|c|}
\hline & Test Pit 1 & Test Pit 2 & Test Pit 3 & Total \\
\hline horizontal incised single line & 0 & 0 & 16 & 16 \\
\hline horizontal incised multiple line & 11 & 0 & 14 & 25 \\
\hline Coles Creek Incised, var. Coles Creek & 1 & 0 & 3 & 4 \\
\hline Crockett Curvilinear Incised & 1 & 0 & 1 & 2 \\
\hline Hollyknowe Pinched & 0 & 0 & 1 & 1 \\
\hline Belcher Ridged & 3 & 0 & 0 & 3 \\
\hline curvilinear engraved & 0 & 0 & 1 & 1 \\
\hline linear engraved & 0 & 0 & 3 & 3 \\
\hline undecorated polished & 8 & 0 & 14 & 22 \\
\hline undecorated other & 244 & 4 & 366 & 614 \\
\hline Total & 268 & 4 & 419 & 691 \\
\hline
\end{tabular}




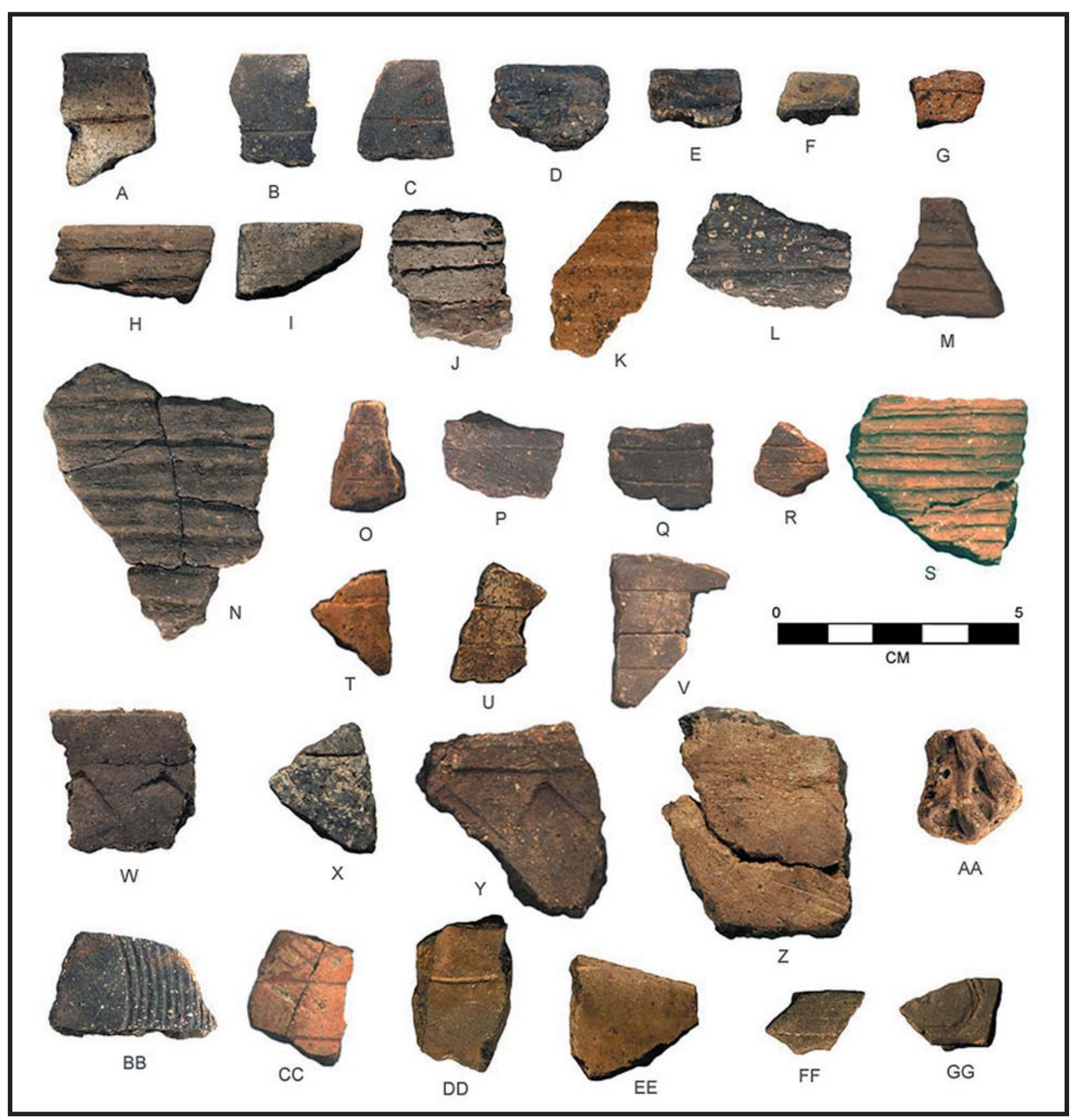

Figure 16. Selected decorated sherds from the Mound 2 area.

Mean sherd thickness is relatively high for the undecorated and Coles Creek specimens (Table 2). Other decorated specimens tend to be slightly thinner, although the incised specimens exhibit considerable variation. Mean sherd thickness over $7 \mathrm{~mm}$ is common in Late Woodland period contexts in the region (e.g., Girard 2005; Schambach 1998), but in later Caddo period contexts, vessel walls tended to be thinner.

Temper was examined using a low-powered magnifying light except for some ambiguous specimens where a binocular microscope was employed at 10x to 20x magnification. All specimens appear to have grog temper, with a small percentage ( $9.4 \%$ overall) containing crushed bone as well (Table 3 ). 


\begin{tabular}{|l|r|r|r|r|}
\hline \multicolumn{5}{|c|}{ Table 2. Thickness $(\mathrm{mm})$ Data for Sherds in the Mound 2 Area } \\
\hline & No. & \multicolumn{1}{|c|}{ Range } & Mean & \multicolumn{1}{c|}{ Std. Dev. } \\
\hline single horizontal line incised & 16 & $3-11$ & 6.125 & 2.125 \\
\hline multiple horizontal line incised & 25 & $4-11$ & 6.280 & 1.568 \\
\hline Coles Creek Incised, var. Coles Creek & 4 & $7-9$ & 8.500 & 1.000 \\
\hline Crockett Curvilinear Incised & 2 & $5-5$ & 5.000 & 0.000 \\
\hline Hollyknowe Pinched & 1 & & 6.000 & 1.000 \\
\hline engraved & 4 & $4-6$ & 5.500 & 0.577 \\
\hline Belcher Ridged & 3 & $5-6$ & 5.333 & 1.192 \\
\hline undecorated, polished & 22 & $4-8$ & 5.091 & 1.894 \\
\hline undecorated, other & $582 *$ & $3-15$ & 7.390 & \\
\hline \multicolumn{2}{|c|}{$*$} \\
\hline
\end{tabular}

\begin{tabular}{|l|r|r|r|}
\hline \multicolumn{4}{|c|}{ Table 3. Temper Categories for Sherds in the Mound 2 Area (row percentages) } \\
\hline & grog & grog and bone & \multicolumn{1}{|c|}{ Total } \\
\hline single horizontal line incised & $14(87.5)$ & $2(12.5)$ & 16 \\
\hline multiple horizontal line incised & $23(92.0)$ & $2(8.0)$ & 25 \\
\hline Coles Creek Incised, var. Coles Creek & $4(100.0)$ & $0(0.0)$ & 4 \\
\hline Crockett Curvilinear Incised & $1(50.0)$ & $1(50.0)$ & 2 \\
\hline Hollyknowe Pinched & $1(100.0)$ & $0(0.0)$ & 1 \\
\hline engraved & $4(100.0)$ & $0(0.0)$ & 4 \\
\hline Belcher Ridged & $3(100.0)$ & $0(0.0)$ & 3 \\
\hline undecorated, polished & $19(86.4)$ & $3(13.6)$ & 22 \\
\hline undecorated, other & $557(90.7)$ & $57(9.3)$ & 614 \\
\hline Total & $626(90.6)$ & $65(9.4)$ & 691 \\
\hline
\end{tabular}

\section{Stone Artifacts}

Classification and distribution of the stone artifacts is presented in Table 4. Raw materials used for stone tool production consist almost entirely of local chert pebbles (152 of the 159 specimens, 95.6\%). Most are tan or dark red, but various shades of gray, black, and white specimens are represented as well. All seem to be within the range of locally observed pebbles-no distinct Ozark or Central Texas cherts were noted. Other materials represented consist of four flakes of fine-grained quartzite, one angular fragment of sandstone, one angular fragment of silicified wood, and one arrow point of novaculite.

\begin{tabular}{|l|r|r|r|r|}
\hline \multicolumn{5}{|c|}{ Table 4. Stone Artifacts from the Mound 2 Area (column percentages) } \\
\hline & \multicolumn{1}{|c|}{ Test Pit 1 } & \multicolumn{1}{|c|}{ Test Pit 2 } & \multicolumn{1}{c|}{ Test Pit 3 } & \multicolumn{1}{c|}{ Total } \\
\hline flakes & $30(73.2)$ & $11(73.3)$ & $60(58.3)$ & 101 \\
\hline angular fragments & $11(26.8)$ & $4(26.7)$ & $29(28.2)$ & 44 \\
\hline pebble cores & 0 & 0 & $5(4.9)$ & 5 \\
\hline flake bifaces & 0 & 0 & $9(8.7)$ & 9 \\
\hline Total & 41 & 15 & 103 & 159 \\
\hline
\end{tabular}

Of the 101 flakes, 38 specimens have cortical striking platforms, 10 have single-facet platforms, one has a multi-faceted platform, 23 have crushed platforms, and the remaining specimens are distal flake fragments. Cortex is present on 75 of the 101 flakes (74.3\%). The high percentage of specimens with cortex and the almost total lack of faceted platforms suggest that chipping activities were confined largely to the splitting of chert pebbles, probably for production of flakes and angular fragments for expedient use without further retouch. However, two specimens, a flake of black chert and an angular fragment of tan chert have retouch flake scars along portions of their margins. The manufacture of arrow points appears to have been carried out occasionally, as at least two specimens probably represent unfinished points (Figure 17C, G), and two fragments (Figure $17 \mathrm{H}, \mathrm{I})$ may represent portions of specimens broken during manufacture. 


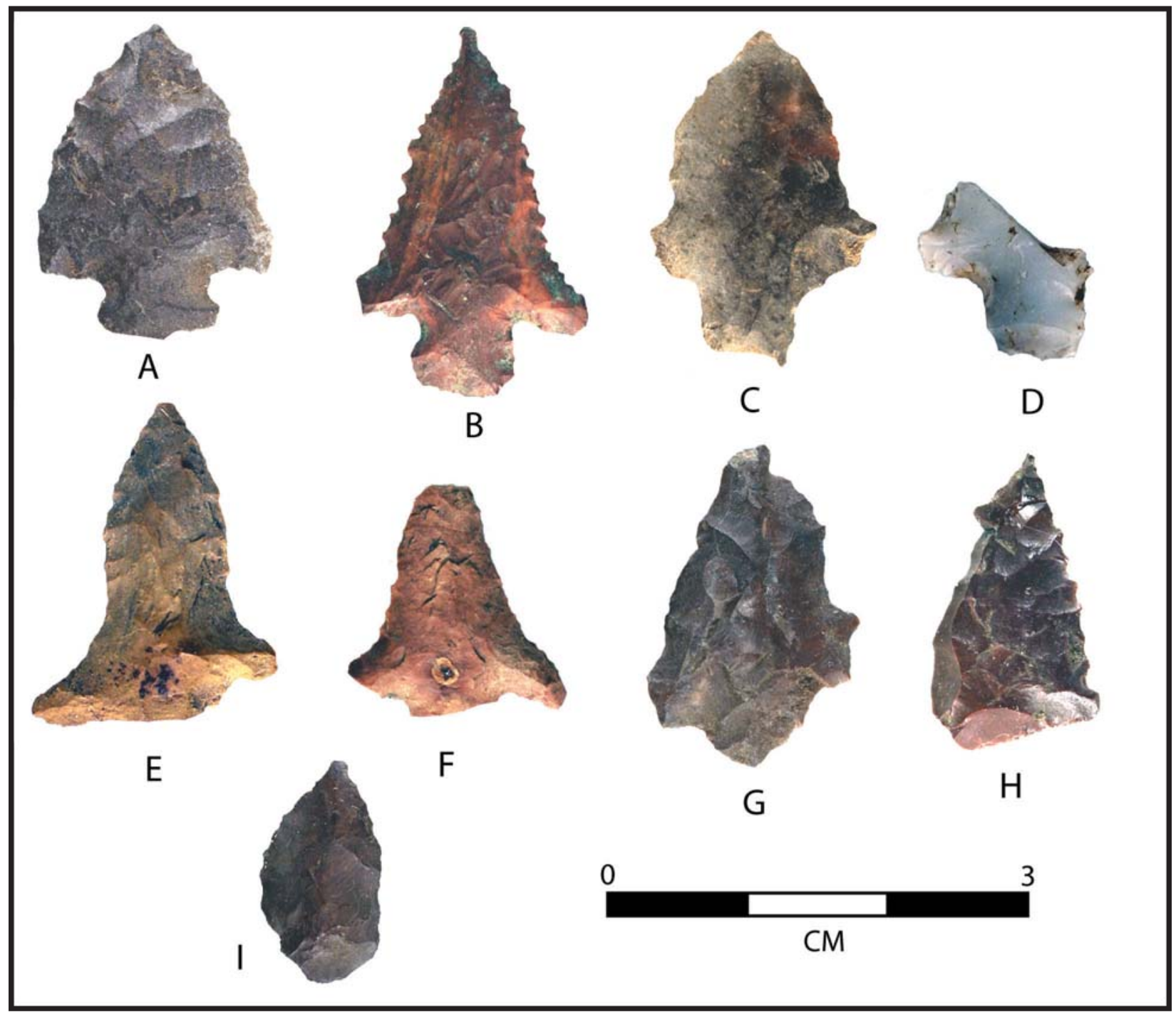

Figure 17. Arrow points from the Mound 2 area.

Nine flake bifaces were recovered from the test units in the Mound 2 area. Arrow point forms are similar to those found previously at Mounds Plantation and other Early Caddo period sites in the region. Two specimens (Figure $17 \mathrm{~A}, \mathrm{~B}$ ) have slightly expanding stems with straight bases and appear to relate to Webb's (2000:16) Colbert type. The other two points with stems (Figure 17 C,D), including a novaculite specimen (Figure 17 D), have rectangular stems and relate to the widespread Alba type (Webb 2000:14). Webb and McKinney (1975) reported Colbert points only from Burial 12 in Mound 5, a single interment containing exclusively arrow points as burial goods. Burial 12 apparently was made prior to construction of the bulk of Mound 5 during what Webb considered to be the Coles Creek occupation of the site. Alba points were the most numerous forms reported by Webb and McKinney (1975:Table3), and were found both as surface finds and in burial contexts. The remaining two recovered arrow points (Figure $17 \mathrm{E}, \mathrm{F}$ ) have prominent shoulders but the stems are missing. One specimen (Figure $17 \mathrm{G}$ ) appears to be a preform, and two (Figure $17 \mathrm{H}, \mathrm{I}$ ) are fragments. 


\section{Test Unit in Mound 5}

According to Webb and McKinney (1975:47), the former landowner removed the upper two-thirds of the western portion of Mound 5 in 1959 and additional fill from the top of the eastern portion in the following year. Bone fragments and Belcher Ridged sherds were uncovered suggesting that a human burial was disturbed. In the fall of 1960, McKinney was allowed to excavate remaining portions of the mound. Webb participated intermittently, and, along with Robert Plant, made notes, photographs, and drawings. Although the exact locations of the excavations are not known, a map made by Webb showing the location of the property boundary on the eastern side of the site enables us to make a reasonable plot of the trenches and units on our contour map (Figure 18).

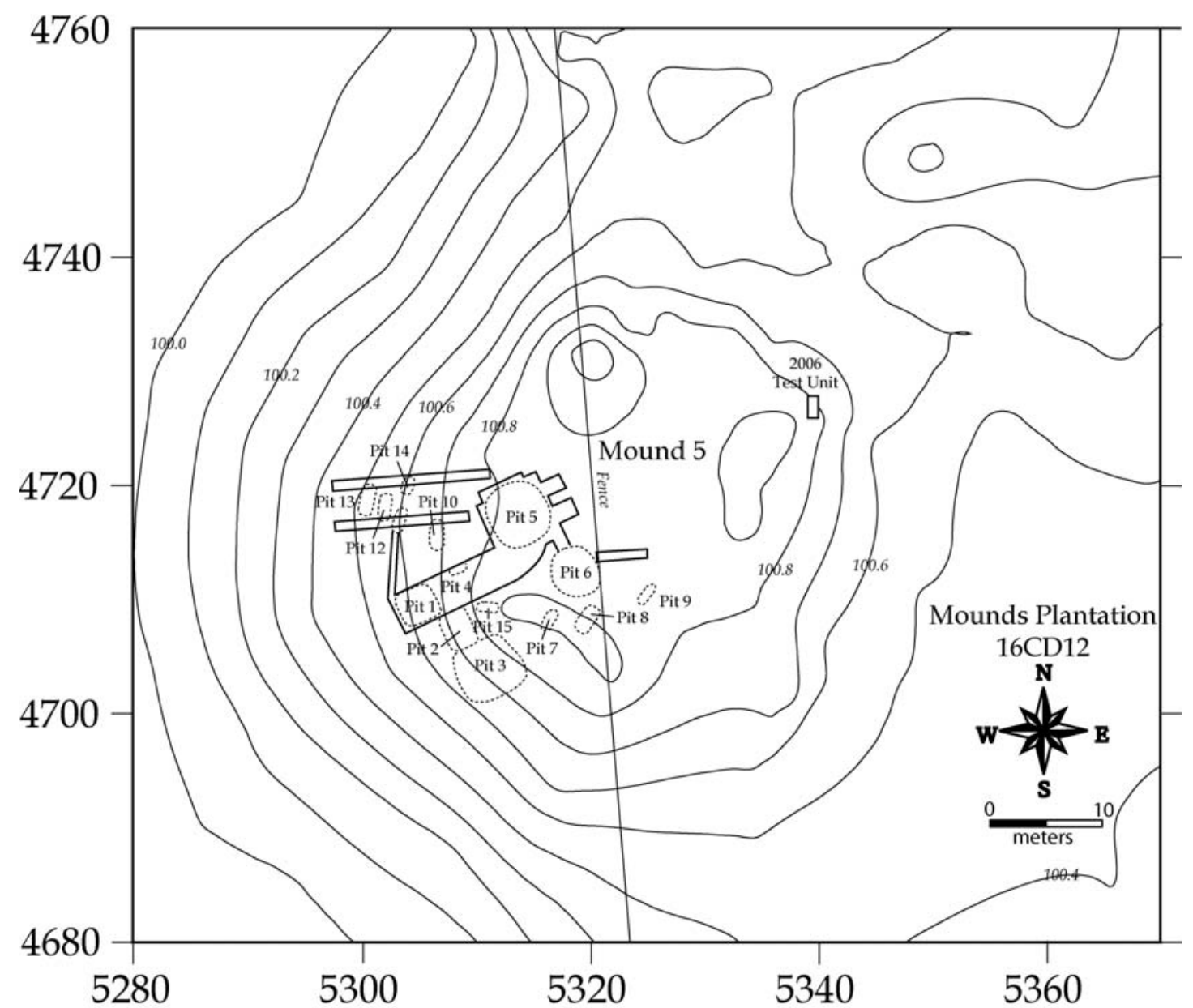

Figure 18. Contour map of Mound 5 showing excavation units.

Near the top of the mound (within the upper $50 \mathrm{~cm}$ ), two burials were encountered, both with ceramic vessels relating to the Late Caddo period (see Webb and McKinney 1975). Four trenches were then excavated into the mound. In Trench 1, the pre-mound surface was encountered at $2.7 \mathrm{~m}$ below the crest of the mound. Although the situation was not completely clear, it appeared that the mound was constructed in at least two stages. There was no evidence of midden accumulation or soil development on top of the primary mound which was approximately $1.2 \mathrm{~m}$ high. A summary of the burial pits encountered during the excavations is presented below. For more detailed information, and descriptions of the recovered artifacts, see Webb and McKinney (1975). Cross sections and a planview presented in that paper are reproduced here as Figures 19 and 20. 

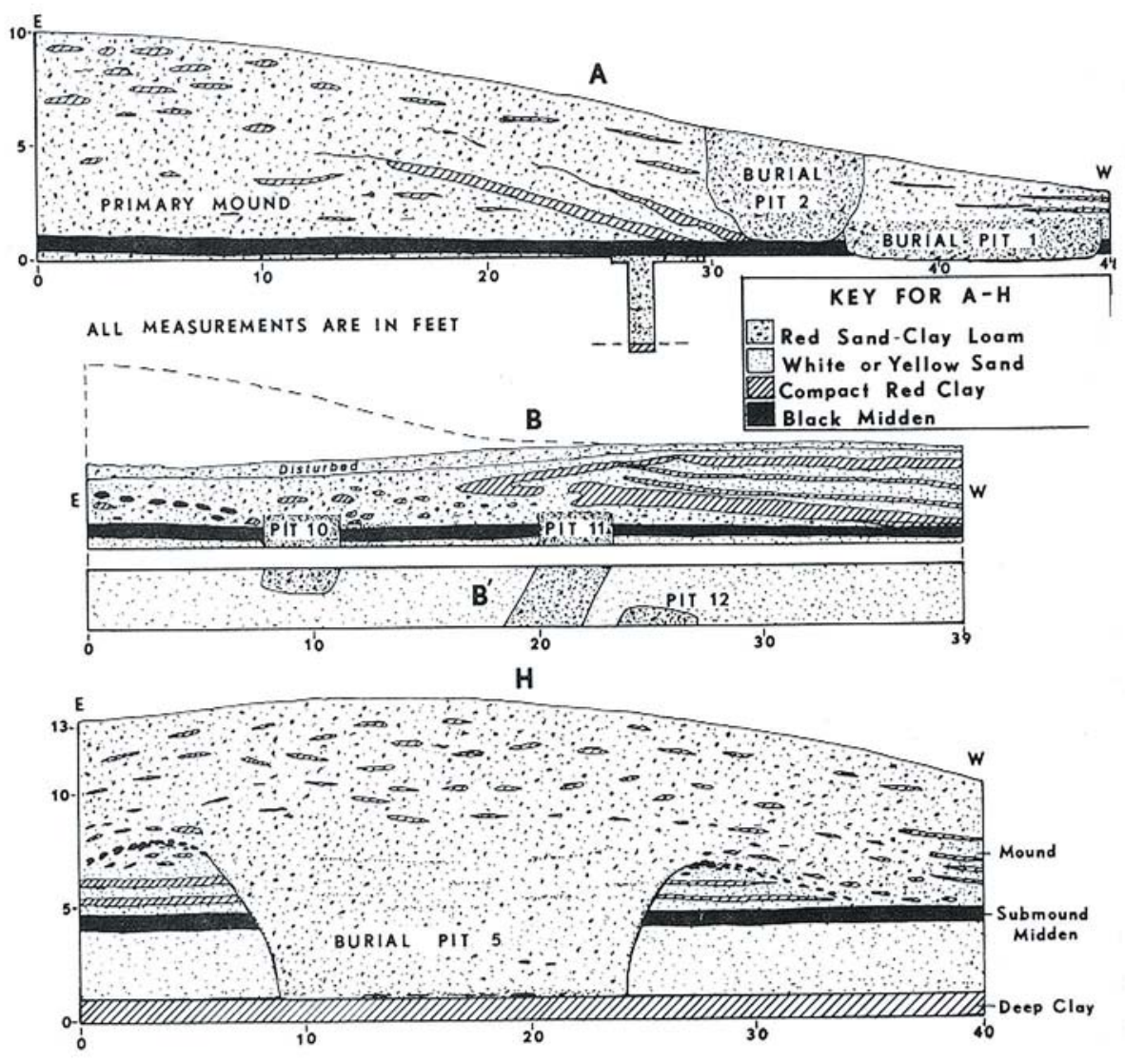

Figure 19. Mound 5 Profiles from Webb and McKinney (1975: Figure 7).

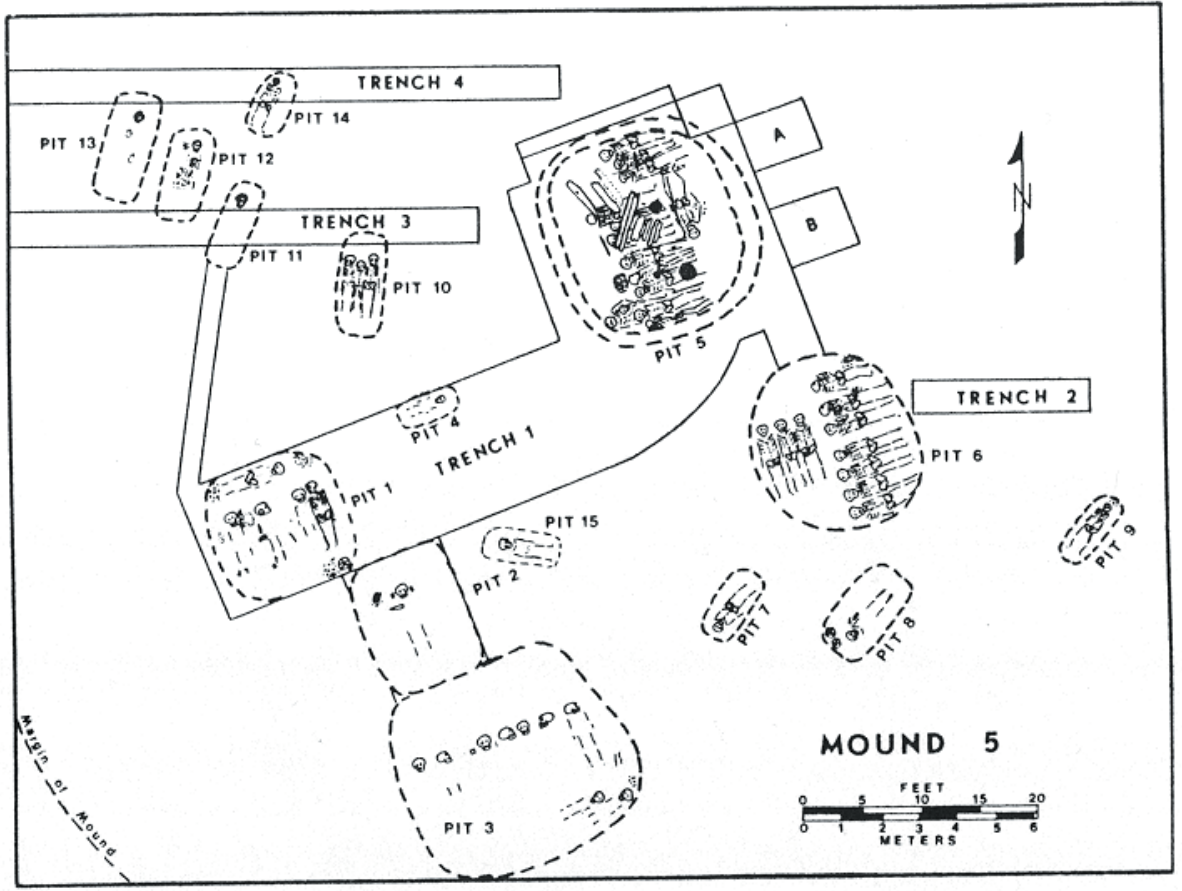

Figure 20. 1960 Excavation Units into Mound 5 from Webb and McKinney (1975: Figure 4). 
Burial Pit 6 was placed through the primary mound and represents one of the earliest burials discovered in the Mound 5 excavations. Seven individuals were placed in a row with heads to the southwest. Above their heads were three additional individuals with heads to the northwest. Six other burials encountered in the northwestern portion of the mound (Burial 4 and Burials 10 through 14) also appeared to relate to the primary mound. Burial Pit 10 had three individuals without burial goods. Burial Pit 12 contained a single individual. Stains suggested that litter poles and possibly fabric were present. Finally, Burial Pits 4, 11, and 14 also had single individuals with skeletal material in poor condition. No grave goods were present.

Burial Pit 1 appeared to be in the sand and clay cap that covered the primary mound near the southwestern end. However, it did not appear to originate from the top of the mound and its position in the sequence of burials is not clear. A row of five individuals were present and a sixth individual was perpendicular on the north side about $20 \mathrm{~cm}$ above the base of the pit. Several burial goods were included in Burial Pit 1.

After the primary mound in Mound 5 was capped, a large $(4.6 \times 4 \mathrm{~m})$ central shaft burial (Burial Pit 5) was sunk through the mound into the underlying deposits. The pit contained multiple individuals along with numerous burial goods (see discussion by Webb and McKinney 1975:55-63). Several well-preserved logs overlay the burials. Two radiocarbon determinations on samples taken from these logs relate to the Early Caddo period: $860+/-120$ B.P. (TX55) and 900+/-100 B.P. (M-1446). A third sample 475+/-100 B.P. (TX56) is considerably later, perhaps due to modern contamination or lab error.

Following additional mound construction, six more burial pits were put in Mound 5. Burial Pit 2 began at the mound summit and went through the pre-mound midden to a depth of $1.8 \mathrm{~m}$. A larger pit, Burial Pit 3, was adjacent to Pit 2 at about the same level. Three burial pits were found along the upper slope of the mound on the south side. Burial Pit 7 originated in the primary mound cap and was sunk through the pre-mound midden. Burial Pits 8 and 9 apparently were in the same stratigraphic context. Finally, human skeletal material in poor condition washed out of the upper mound slope south of Trench 1 was labeled Burial Pit 15.

In an attempt to determine the condition of the remaining moundfill and nature of the sub-mound deposits, we excavated a 1-x-2-m test unit on the eastern edge of the remaining rise in January 2006. The excavations were conducted in $10 \mathrm{~cm}$ horizontal levels and the fill was screened through $1 / 4$-inch mesh. The unit went through the mound remnant (Strata 1 and 2), into the sub-mound 2A and 2C soil horizons. A large pit feature (Feature 2) with a ring of dense red clay (Feature 1) around its upper periphery was partially exposed. Distinct loadings within Feature 2 were assigned separate designations (Feature 2A through 2E). A small pit feature (Feature 3), likely to represent a posthole, was encountered adjacent to Feature 2. Each of the deposits and features is described below.

\section{Stratum 2}

Stratum 2 consists of very fine sandy loam sediments that constitute the uppermost remaining moundfill (Figure 21, Figure 22). A weakly developed soil is developed in the fill with the upper 10 to $12 \mathrm{~cm}$ (A horizon) slightly darker (7.5YR3/2) in color than the underlying deposits (C horizon) (7.5YR3/4). The deposits were homogeneous in color, with no evidence of basket loads. Roots were numerous and there was evidence of rodent burrowing. Early $20^{\text {th }}$ century artifacts were scattered throughout the stratum. A tenant farm house was located on top of the mound until 1959 when the structure was dismantled and the surface leveled. Four undecorated, grog-tempered sherds also were recovered in this stratum. 

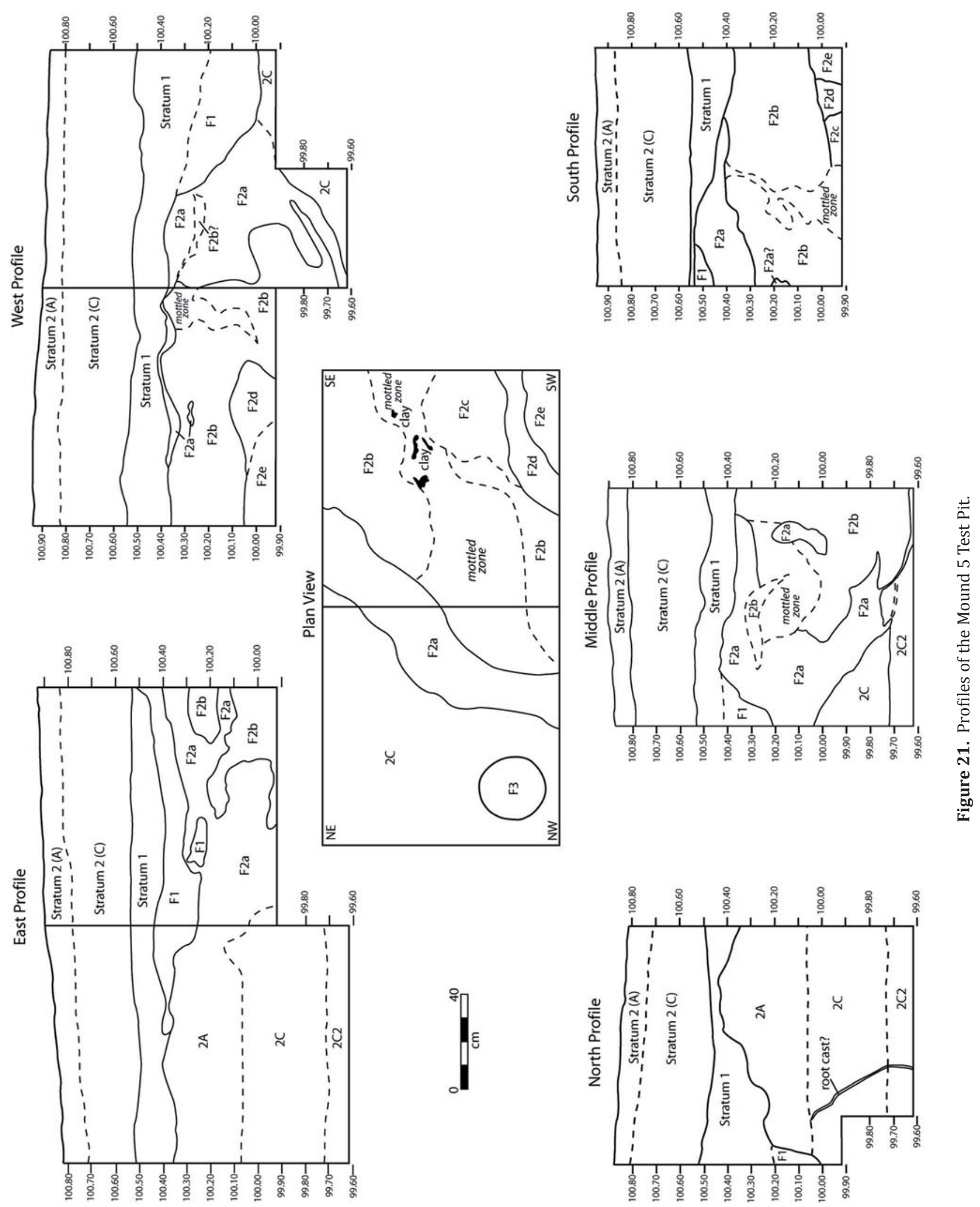


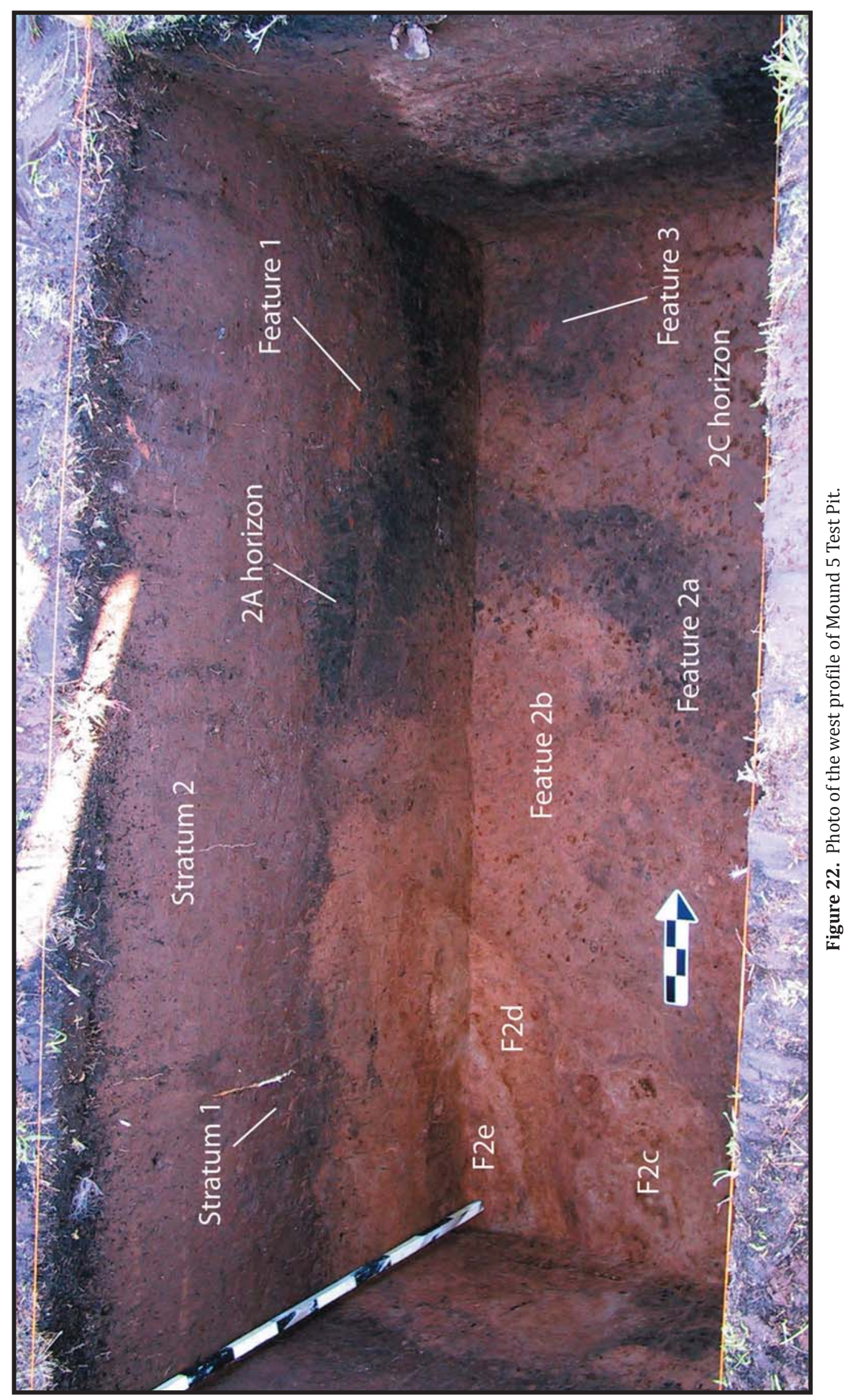


Stratum 1

Underlying Stratum 2 was a layer of dark reddish brown (5YR3/3) clay. The boundary with the overlying deposits ranged from level to wavy. The lower boundary with the 2A horizon was wavy. In some areas (particularly the northwest corner of the unit), Stratum 1 appears to dip into the 2A horizon. Stratum 1 was generally 15 to $20 \mathrm{~cm}$ thick, but almost pinched out in the north profile (see Figure 21). A few historic artifacts were recovered, apparently having been displaced by bioturbation from Stratum 2. The clay appeared chunky rather than massive, and likely represents a clay base to the mound rather than a natural alluvial deposit. The clay that overlies the buried A horizon along the terrace edge is similar in color, but, as noted in the Mound 2 area discussion, is a natural deposit that accumulated long after the site was abandoned. Webb included discontinuous strata of red clay in his Mound 5 profiles (see Figure 19). He noted that, along the lower slopes, a clay layer of about the same thickness as Stratum 1 directly overlay the submound midden, then rose toward the mound center capping the primary mound (Webb and McKinney 1975:50-51).

\section{Submound Deposits.}

The upper deposits (2A horizon) of the land surface directly beneath Stratum 1 were dark brown (7.5YR3/2) very fine sandy loam. Small chunks of clay were present throughout due to leaching of Stratum 1. The 2A horizon was truncated by Feature 2 in the southern portions of the unit. A gradual boundary separated the $2 \mathrm{~A}$ and $2 \mathrm{C}$ horizons of the submound terrace deposit. The $2 \mathrm{C}$ horizon consists of a brown (7.5YR4/4) to strong brown (7.5YR4/6) very fine sandy loam. Red and gray mottles increased with depth and by about 99.70 $\mathrm{m}$ they constituted at least half of the deposits (2C2 horizon).

\section{Feature 1.}

Feature 1 consisted of a dark reddish brown (2.5YR3/4) clay that was present intermittently along the margins of the large Feature 2 pit. The feature clearly intruded into the 2A horizon (see Figure 22). Feature 1 directly underlay Stratum 1 and was distinguished from it by its slightly redder color and chunkier nature. In the east profile, the upper boundary is gently concave and has an overall basin shape. The clay deposits were clearly loaded in chunks, some of which are isolated in the 2A deposits. The Feature 1 deposits were not present over the central portion of Feature 2. Webb plotted small lenses of compact red clay throughout the mound fill. Although the test pit obviously only samples a small area, it appears that the Feature 1 clay is associated with the Feature 2 pit.

A single brushed sherd was recovered in the Feature 1 clay. Brushing is not a common surface finishing technique at Mounds Plantation, although Webb and McKinney (1975:Table 2) reported 15 specimens. Brushed utilitarian jars became dominant after about A.D. 1200 (Middle Caddo period) in the region, but have been reported from other Early Caddo period contexts (Webb 1983:192).

Feature 2.

Feature 2 appears to be the northwest corner of a large, submound pit, probably similar to the burial pits encountered on the west side of the mound by McKinney and Webb. The complete outline of the feature was not exposed, but it is likely to be a slightly squared oval, similar to the other large burial pits (Pits $1,3,5$, and 6 - see Figure 20). The orientation, with the long axis slightly northwest to southeast, also appears the same.

The Feature 2 deposits are subdivided into five units for descriptive purposes. Feature 2A appears to represent 2A horizon sediments that line the upper margins of the pit. These sediments are thickest at the top of the feature, and thin out into lenses with depth (best seen in the middle and west profiles of Figure 15). These sediments also became thinner over the interior portions of the feature (as seen in the east and south profiles of Figure 21). 
Feature $2 \mathrm{~b}$ is the primary fill of the pit. It apparently was basket loaded and varies in color with strong brown (7.5YR4/6), reddish brown (5YR5/4), and yellowish red (5YR4/6) dominant, and numerous grayer patches. The texture generally was a very fine sandy loam, but small patches of gray clay were present. Features 2c, 2d, and 2e appear to represent three distinct loadings. The fills are multi-colored. All are present in the southwest corner of the test unit. Feature $2 \mathrm{C}$ is the outermost fill and present primarily in planview at the $99.92 \mathrm{~m}$ level (see Figure 21). The fill is similar to the surrounding Feature 2b, but contains more gray mottles. Feature $2 \mathrm{~d}$ is separated from $2 \mathrm{c}$ by a thin reddish brown band. The boundaries are well defined in both the south and west profiles, as well as in planview. The feature appears to have cut through (and thus postdates) Feature 2c, and extends farther to the north. Feature 2e lies entirely within Feature 2d, and might simply represent a basket load within the fill. The outer fill consists of a gray band with a very thin dark reddish brown band around its perimeter. None of the inner features appear to extend to the top of Feature 2, but rather have a distinct upper boundary that slants down from west to east from approximately the 100.05 level to the 99.95 level, suggesting that the deposits were loaded as the Feature 2 pit was filled. However, this is not completely clear and the possibility that the pit was filled, partially re-opened, and re-filled on more than one occasion cannot be dismissed.

\section{Feature 3.}

Feature 3 is a dark oval area, approximately $27 \mathrm{~cm}$ by $30 \mathrm{~cm}$ in size at the $99.92 \mathrm{~m}$ level, visible beneath the $2 \mathrm{~A}$ horizon in the northwest corner of the test unit (see Figure 20). The fill at the upper level was similar to the $2 \mathrm{~A}$ horizon - very fine sandy loam, 7.5YR3/2, with a grayer more mottled zone along the south and east sides (Figure 23). The feature was left on a pedestal as the surrounding deposits were excavated to $99.62 \mathrm{~m}$, and later was cross sectioned. The dark deposits continued to a depth of about $99.76 \mathrm{~m}$. Beneath these was a mottled zone that tapered to the base of the excavation. It is possible that the mottled zone represents a posthole, with the darker area the decayed remains of a post. Although the top of the $2 \mathrm{~A}$ horizon (the premound surface) is truncated by Stratum 1 in this area, it likely was about the $100.40 \mathrm{~m}$ level, indicating that the posthole was about $80 \mathrm{~cm}$ deep and the post set about $64 \mathrm{~cm}$ deep. Stratum 1 was visible across the northwest corner of the unit and was not cut through by Feature 3. Thus the upper portion of the post must have been broken or removed prior to deposition of Stratum 1.

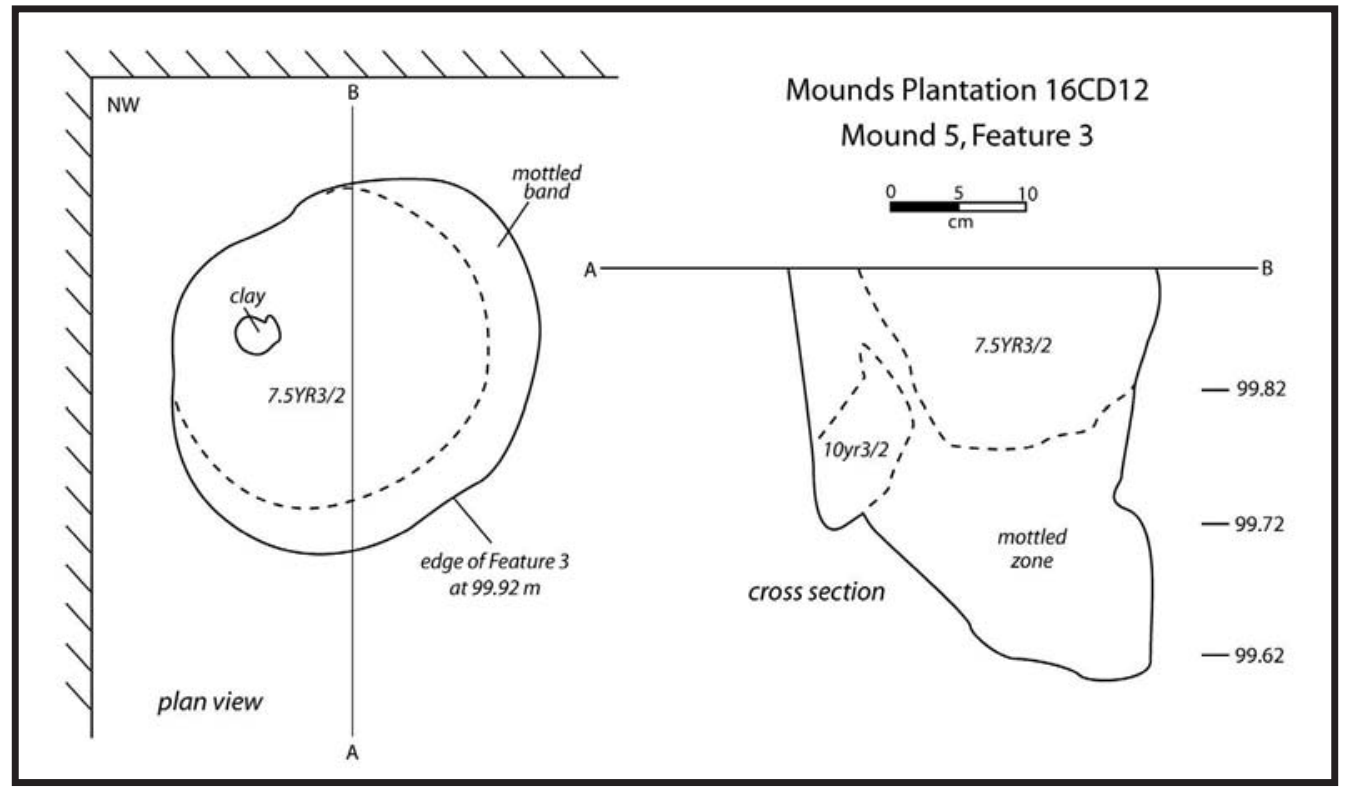

Figure 23. Plan view and cross section of Feature 3, Mound 5. 


\section{Discussion}

Although the upper portion of Mound 5 has been removed, the test unit clearly shows that at least $50 \mathrm{~cm}$ of fill remains on the eastern side. The investigations also demonstrate that additional burial pits and other features are likely to be present in the submound deposits. Out of respect for the Caddo people, and in accordance with Louisiana state law, we did not continue excavation into Feature 2 and clearly demonstrate that it represents a burial pit. However, similarities to some of the burials pits described by Webb and McKinney (1975) leave little doubt that the feature relates to a burial that was interred prior to placement of the lowest mound deposit (Stratum 1), and thus might represent one of the earliest burial events in the Mound 5 area.

Unfortunately, no charcoal for radiometric dating, or artifacts diagnostic of a particular time period were recovered in the submound deposits. However, the potential for recovering such material appears to be good with more extensive excavations that do not impact human burials.

\section{Investigation of Mound 6}

\section{Description of Mound 6}

Mound 6 is large, about $80 \mathrm{~m}$ x $60 \mathrm{~m}$, similar in size to Mound 1. However, it is only a little more than $50 \mathrm{~cm}$ high. When described by Webb, it was $60 \mathrm{~cm}$ tall and 45-50 $\mathrm{m}$ in diameter. Since that time, Mound $6 \mathrm{does}$ not appear to have been cut down significantly, although it apparently has been spread out by plowing. Webb and McKinney (1975) reported that a barn, garden, and windmill were on the mound summit. According to the landowner, the barn sat on a concrete curb foundation. It was torn down in the 1980s, and large concrete slabs were pushed into the pond to the southeast. The windmill was adjacent to the barn, but blew down during a tornado in the late 1960s. A pump house was located next to the windmill, and an electric high wire crossed above the north side of the mound providing power for the pump. A gravel road ran southeast to northwest on the north side of the mound.

The gradiometer results from 2007 showed two large, intense anomalies, one on the eastern edge of the mound summit and one near the base of the mound on the southeastern slope (Figure 24). A probe excavated in 2007 indicated brick and concrete within a meter of the surface in the first of these, possibly from the base of the former windmill. The downslope anomaly probably is from displaced large concrete slabs that once formed the foundation for the barn. A linear anomaly in the southwestern portion of the gradiometer sample area might be an intact portion of the concrete foundation. At the north end of the mound summit was an area of numerous scattered anomalies. Although most of these were dipole signals likely from historic iron debris, we decided to excavate a shovel test in this area to determine this for certain.

\section{Shovel Test and Test Unit}

We began a 30-x-30-cm shovel test with the southeast corner located at N4823E5054.3. All fill was screened through $1 / 4$-inch mesh. The shovel test later was expanded into a 1-x-1-m unit designated by the southwest corner (N4823E5053) in accordance with our previous procedures. Deposits in the upper 10 to $15 \mathrm{~cm}$ were yellowish red (5YR4/6) very fine sandy loam with a gradual, irregular lower boundary suggesting that this represents the zone regularly disked for cultivation (Figure 25). Underlying the plowzone was reddish brown (5YR4/4) very fine sandy loam that was mottled with small redder and grayer patches easily seen in the unit profiles (Figure 26). This zone likely represents loaded moundfill that has been subject to deep plowing. The landowner noted that past plowing probably penetrated about 2 feet $(60 \mathrm{~cm})$ below surface. The upper moundfill contained chunks of mortar, brick fragments, bottle glass, and gravel, as well as a few Caddo sherds. 


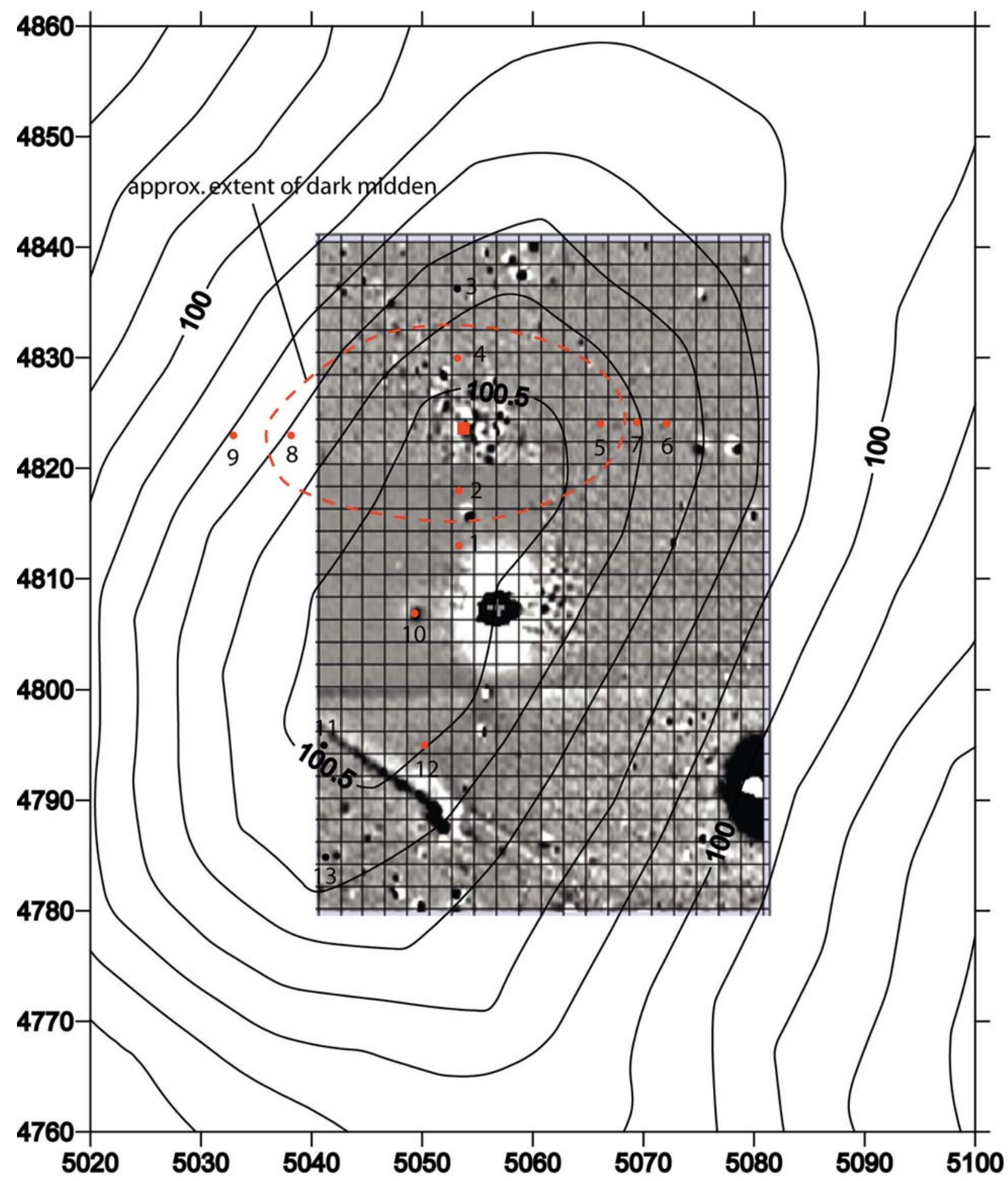

Figure 24. Contour map of Mound 6 with superimposed gradiometer data. Red dots indicate locations of soil probes; the red square is the location of the test unit. 

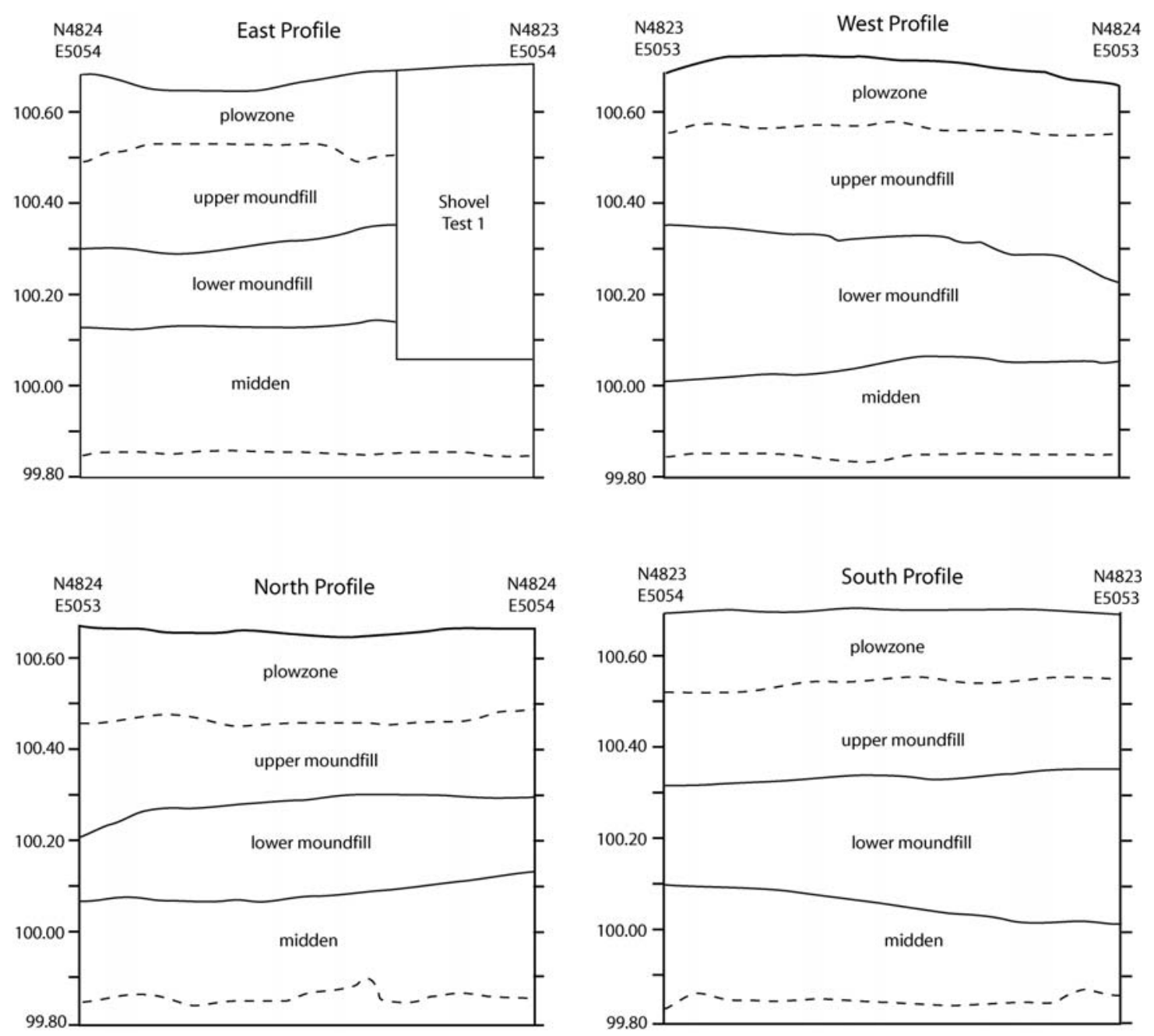

Figure 25. Profiles of the test unit, Mound 6.

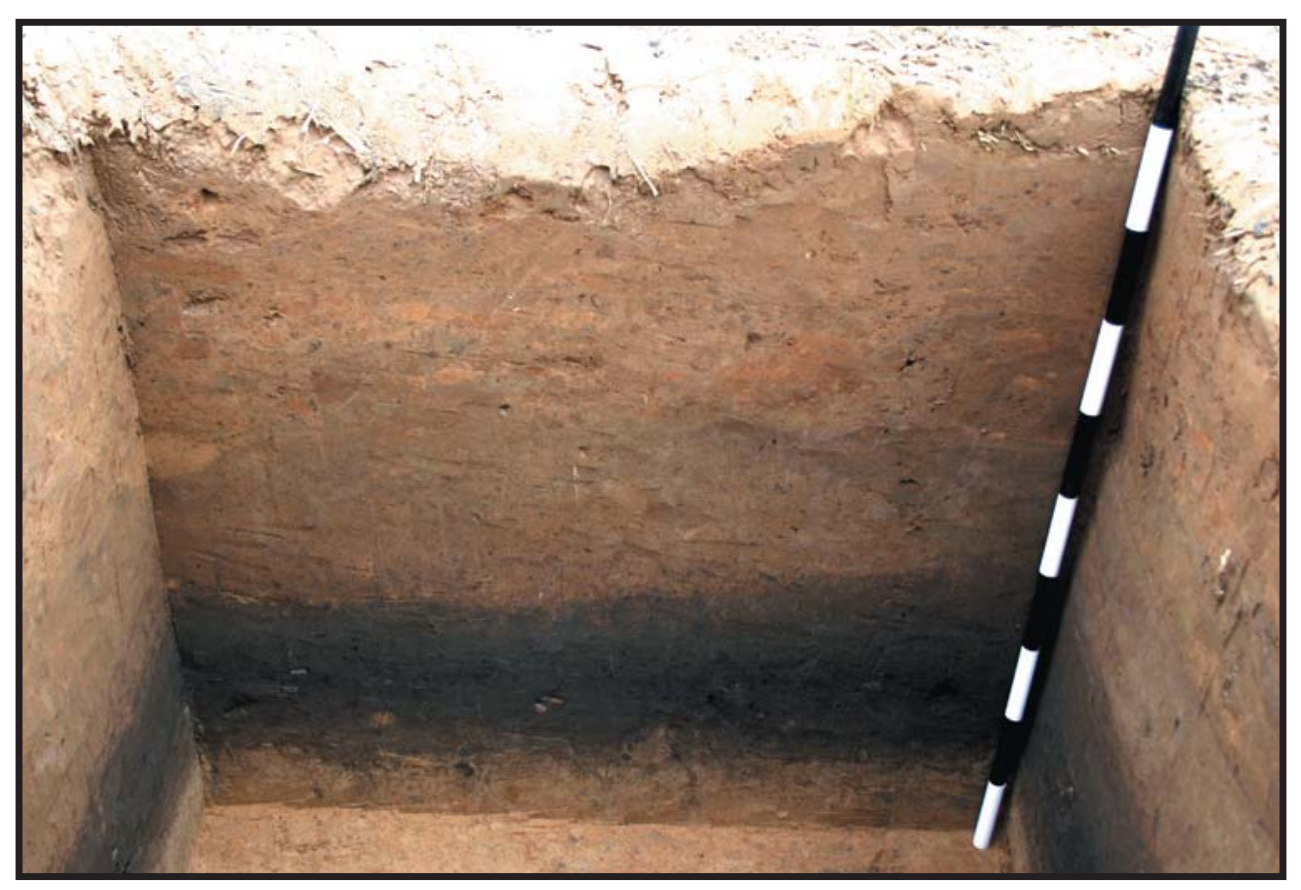

Figure 26. Photograph of the north profile of the test unit, Mound 6. 
Underlying the mottled zone was a layer of significantly more homogeneous reddish brown (5YR4/3) very fine sandy loam (lower moundfill). In places, particularly visible in the north and west profiles, an abrupt horizontal line separated these two zones; the change was more subtle on the west and south sides. The lower moundfill was between about 20 and $35 \mathrm{~cm}$ thick. Deposits were slightly grayer in the upper portion suggesting a possible weakly developed A horizon which might indicate that significant time elapsed between deposition of the lower and upper zones. No historic materials appeared to come from within the lower moundfill and it does not appear likely that plowing penetrated to this depth.

The surface beneath the mound was easily detected between the 100.12 and 100.02 m levels. This surface appeared to dip slightly from the northeast to the southwest. Deposits consisted of very dark gray (5YR3/1) very fine sandy loam with numerous worm casts. Many Caddo sherds and a moderate amount of stone chipping debris were recovered. There was a slight rise in the dark deposits in the northeast corner of the unit, perhaps an accumulation of sediment above the plane of the ground surface in this area. It is possible, however, that the rise simply represents a slightly undulating former ground surface.

A sample of scattered charcoal collected in the sub-mound deposits between 100.00 and $99.90 \mathrm{~m}$ was submitted for AMS radiocarbon analysis. The result [1010 \pm 25 B.P; UGAM06468; wood charcoal; $\delta^{13} \mathrm{C}=-27.0$ ] suggests that the area was occupied in the late $10^{\text {th }}$ or early $11^{\text {th }}$ century.

\section{Soil Probes}

We excavated 13 soil probes across the mound to delimit the extent of the sub-mound dark midden deposits, and to look for additional features. Probes 1 through 9 were placed on the northern portion of the mound to find the extent of the midden sampled by the test unit (see Figure 24). We were able to identify the sub-mound surface in all of the tests. The dark midden deposit ended between Probes 1 and 2 on the north, Probes 8 and 9 on the west, Probes 3 and 4 on the north, and Probes 5 and 7 on the east. Thus, the midden appears to cover an area roughly $30 \mathrm{~m}$ (east-west) by $20 \mathrm{~m}$ (north-south).

Four additional probes were placed in the southern portion of the mound. Probe 10 was placed near an anomaly in the gradiometer data, but did not encounter a distinct feature. The sub-mound surface was detected at $75 \mathrm{~cm}$ below surface and was a dark reddish brown (5YR3/3) fine sandy loam-not as dark as the midden. Similar results were found in Probe 11. Probe 12 had a distinct clay loam fill between 40 and $60 \mathrm{~cm}$. Directly beneath this was the sub-mound surface. Fine sandy loam was encountered at $95 \mathrm{~cm}$ in Probe 13, but we were unsure whether this represented a buried surface. The upper deposits were mottled in this probe and it is possible that there is a Caddo feature within the moundfill or a historic disturbance in this area.

Pottery

Sherds were numerous in the pre-mound deposits, and a few specimens were present in the upper and lower moundfills (Table 5). A total of 198 sherds was recovered, 175 of which (88.4\%) are undecorated. Thirteen rim sherds are undecorated. Four of these are polished on both surfaces and appear to represent bowls. It was possible to measure rim diameters of 26,24 , and $14 \mathrm{~cm}$ on three specimens. All are tapered with thin, flat lips. At least two jars appear to be represented-one with a rim diameter of $15 \mathrm{~cm}$ and another with a relatively wide $30 \mathrm{~cm}$ diameter suggesting a large vessel. 


\begin{tabular}{|c|c|c|c|c|c|c|}
\hline & $\begin{array}{c}\text { shovel } \\
\text { test }\end{array}$ & $\begin{array}{c}\text { upper } \\
\text { moundfill }\end{array}$ & mixed & $\begin{array}{c}\text { lower } \\
\text { moundfill }\end{array}$ & midden & total \\
\hline \multicolumn{7}{|l|}{ Ceramics } \\
\hline undecorated & 2 & 5 & 4 & 11 & 153 & 175 \\
\hline horizontal incised single line & & 1 & & 2 & 6 & 9 \\
\hline Coles Creek Incised, var. Greenhouse or Blakely & & & 1 & & 6 & 7 \\
\hline Coles Creek Incised, var. Hardy & 1 & & & & 2 & 3 \\
\hline Coles Creek Incised, var. Coles Creek & 1 & & & & 0 & 1 \\
\hline engraved & & & & 1 & 2 & 3 \\
\hline clay lumps & & & 4 & & 1 & 5 \\
\hline \multicolumn{7}{|l|}{ Lithics } \\
\hline flakes & 1 & 5 & 5 & 6 & 47 & 64 \\
\hline pebble cores & & & & & 5 & 5 \\
\hline angular fragments & 1 & 2 & & 2 & 14 & 19 \\
\hline sandstone/ironstone chunks & & & & & 2 & 2 \\
\hline Burned bone fragments & & & & 3 & 9 & 12 \\
\hline
\end{tabular}

Most decorations consist of horizontal incised lines, probably on the upper portions of vessels. Three specimens have multiple lines spaced at close (less than $1 \mathrm{~cm}$ ) intervals (Figure $27 \mathrm{~A}-\mathrm{C}$ ). These are classified as Coles Creek Incised, var. Hardy. Two of these are rim sherds, probably from jars of unknown rim diameter. Eight specimens have only a single incised line (Figure $27 \mathrm{D}-\mathrm{K}$ ). Some of these may be from vessels with multiple widely-spaced lines, but the specimens are too small to tell for certain. Two are rim sherds with relatively thick flat lips and may be from bowls. Seven specimens have widely-spaced horizontal incised lines (Figure 27 L-0). These sherds are similar to the Greenhouse and Blakely varieties of the type Coles Creek Incised (Phillips 1970). One small sherd has the distinctive triangular punctations of Coles Creek Incised, var. Coles Creek (Figure 27 R). The sherd is broken above the row of punctations and no incised lines are present. Three sherds are typed as engraved, although the distinction between fine incising and engraving is somewhat subjective. Two have only single lines (Figure $27 \mathrm{P}-\mathrm{Q}$ ). The third (not illustrated) has very faint multiple parallel lines.

Although decorative characteristics of the recovered specimens resemble the type Coles Creek Incised, paste attributes are similar to other pottery from Mounds Plantation and other sites in northwest Louisiana. In contrast to much Lower Mississippi Valley Coles Creek pottery, there tends to be considerable amounts of fine sand in the fabric and four specimens also contain crushed bone.

\section{Stone Artifacts}

All recovered stone from the Mound 6 unit appears to represent chipping debris-no tools or tool fragments were found. Local chert specimens consist of 64 flakes, 19 angular fragments, and five pebble cores. We also recovered a chunk of ferruginous sandstone and a chunk of ironstone-neither appear modified. Of the 64 recovered flakes, 18 have cortical striking platforms, seven have single facet platforms, three have multiple facet platforms, 12 have crushed platforms, and 24 are distal flake fragments lacking platforms. Cortex is present on $42(65.6 \%)$ of the 64 flakes. The chipping debris is similar to that recovered near Mound 2. It appears that the stone technology focused on splitting chert pebbles to produce useable flakes, rather than production of formally retouched tools. 


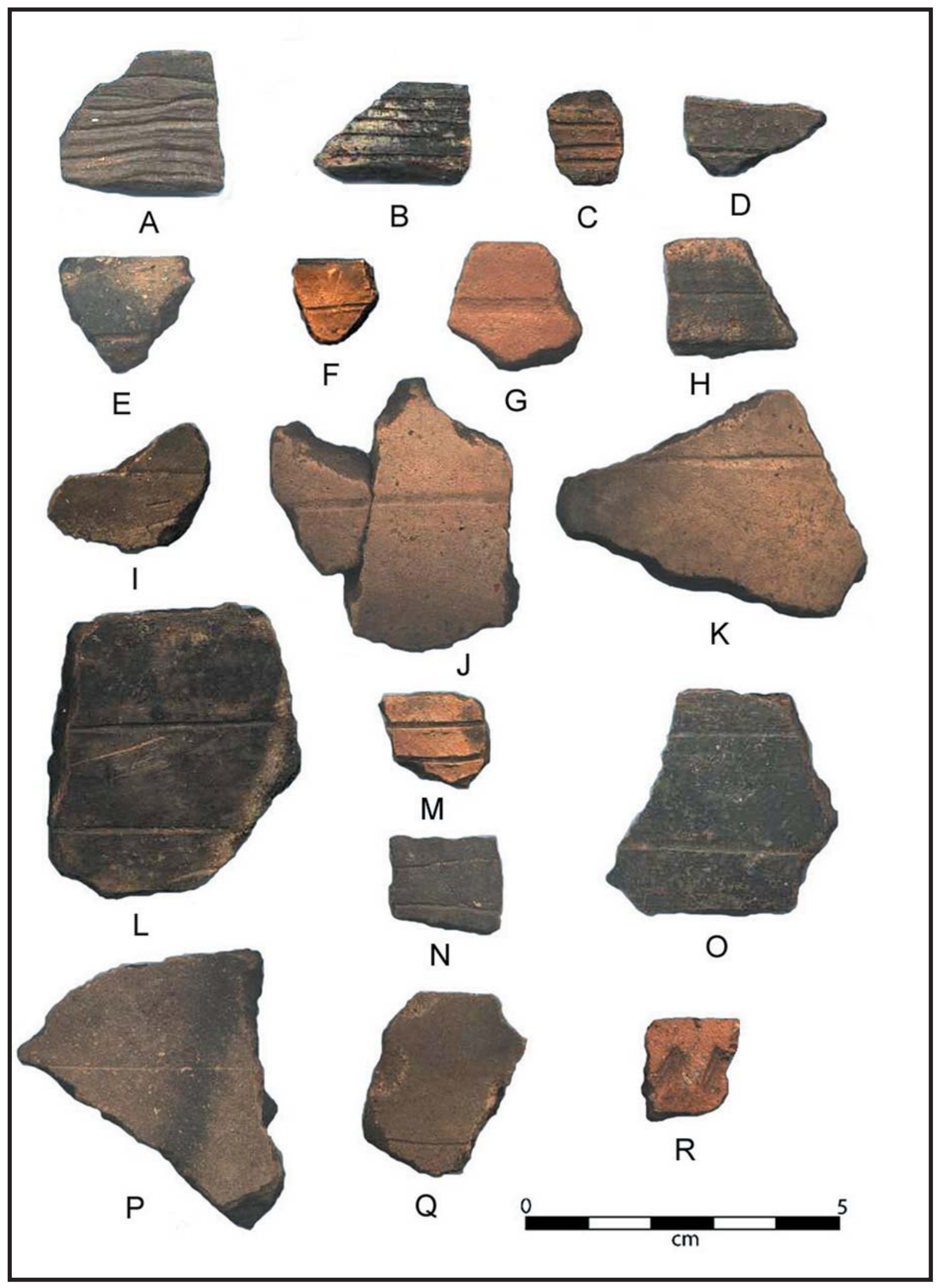

Figure 27. Decorated sherds from test unit, Mound 6. 


\section{Current Conditions of the Other Mounds}

Mound 1

Veatch (1899) estimated that the top of "Treasure Mound" (probably Mound 1) was about 75 x $75 \mathrm{ft}$ in extent. However, Moore, also apparently describing Mound 1, measured the summit-plateau at 145 x $90 \mathrm{ft}$. Our current estimate is close to this-in the $45 \times 30 \mathrm{~m}$ (148 x $98 \mathrm{ft})$ range. Removal of upper portions of the mound between Veatch and Moore's observations could account for the increase in size of the summit. Veatch (1899) estimated the mound to be $16 \mathrm{ft}$ high and Moore regarded the height as a "trifle more than $15 \mathrm{ft}$ ". Webb and McKinney (1975:43) stated that Mound 1 was cut down when the landowner's house was constructed (about 1925), and the mound now is between 2.5 and $2.7 \mathrm{~m}$ high or about $8.5 \mathrm{ft}$ tall —a little over half the height reported by Veatch and Moore. The present landowners, there since the early 1960s, have not altered Mound 1. The house remains on the top and the area is planted in grass with no substantial erosion evident (Figure 28). Barns and other outbuildings are situated on the north and west sides. The mound is roughly quadrilateral with a flat top, steep sides, and no trace of a ramp. Moore measured the base at $220 \mathrm{ft} x 160 \mathrm{ft}$. Currently the base seems larger (approx. 81 x 63 m or 266 x $207 \mathrm{ft}$.), although the edges are not easily defined. Mound 1 has not been plowed and the difference could be due to broadening of the base from slopewash. It should be noted that Webb (Webb and McKinney 1975:40) thought that Moore described Mounds 2 and 5 . I agree that Moore first describes Mound 2, but think it more likely that the second mound described (Moore 1912:438) was Mound 1 rather than Mound 5.

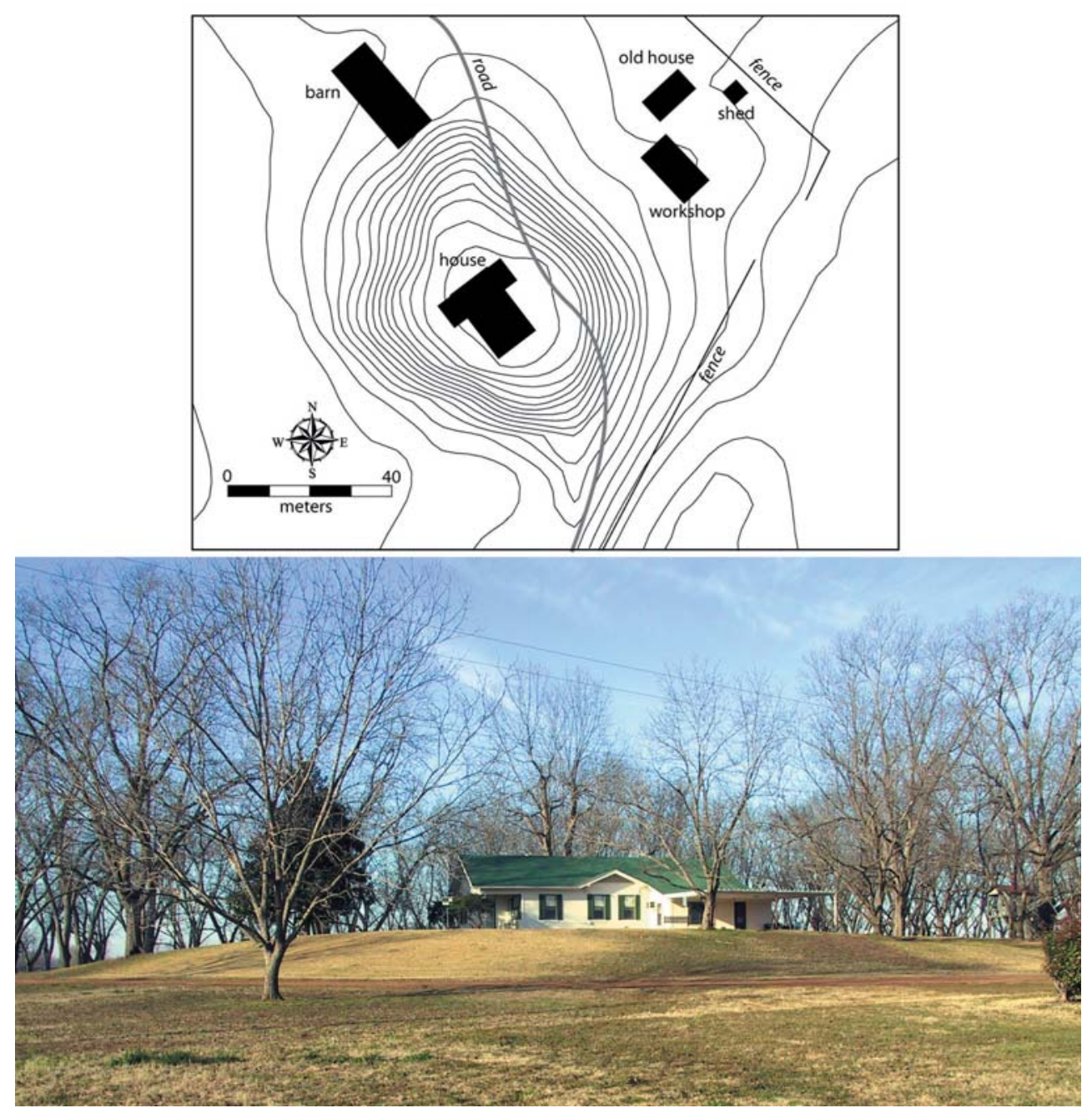

Figure 28. Contour map of Mound 1 (upper) and photo looking southwest at the mound (lower). 
Mound 3

When visited by Webb and McKinney in the early 1960s, Mound 3 had a flat top that was about $3 \mathrm{~m}$ high, and $36 \mathrm{~m}$ in diameter. The mound now is only about $50 \mathrm{~cm}$ tall, but the diameter is similar to that reported by Webb-actually somewhat larger probably from dispersion by plowing. It is not possible to ascertain the edges of the mound based on the surface topography. Deposits at the mound summit are sandy, contrasting with the surrounding clay.

In 1959, the landowner removed the tenant house on the summit, and had begun to level the deposits when he encountered a human burial. Ralph McKinney, a local rancher with an interest in archaeology, was notified and allowed to excavate a 30-m-long, 3.35-m-wide, trench through the center. Webb visited the site when the trench was open and made a schematic cross section (Figure 29). Above a thick dark midden that underlay the mound were two small, mounded areas capped by thin, dark midden zones. One of the small mounds contained a layer of ash within it. Additional fill consisting of sand mixed with lumps of clay formed the bulk of the overlying mound, which was capped by a thin midden layer. Concentrations of pottery and animal bone were found in the middens and Webb suggested that food preparation for ritual feasts was carried out in the area. At least two human burials were later placed in the top of the mound. The contents of the first burial, encountered by the landowner, are not known. McKinney found a second burial that included ceramic vessels dating to the Late Caddo period.

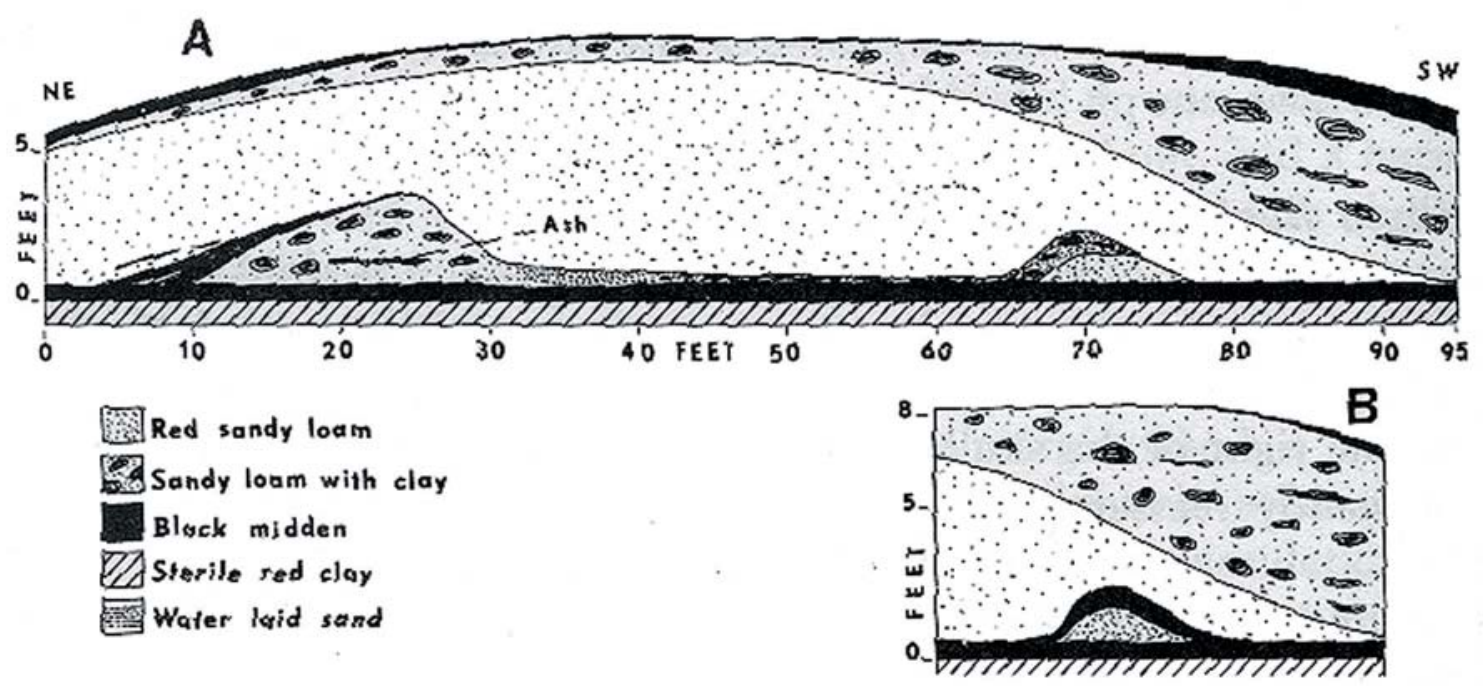

Figure 29. Cross sections of Mound3 from Webb and McKinney (1975: Figure 2).

Webb suggested that Mound 3 was built over the remains of a structure and became an area were cooking and ceremonial feasting took place (Webb and McKinney 1975:47). Mound 3 now is only about $50 \mathrm{~cm}$ tall, but the diameter is similar to that reported by Webb-actually somewhat larger probably from dispersal by plowing. It is not possible to ascertain the edges of the mound based on the surface topography. Deposits at the mound summit are sandy contrasting with the surrounding clay. It is unfortunate that we no longer have the faunal remains recovered within Mound 3. 
In November 2005, I excavated a 4-inch bucket auger test on the northeast edge of Mound 3, in clay surface deposits just beyond the sandy summit of the mound. The upper $30 \mathrm{~cm}$ were composed of dark reddish brown (5YR3/3) silty clay. The clay was underlain by reddish brown (5YR4/4) silt loam that graded to yellowish red (5YR4/6) by $80 \mathrm{~cm}$. Although plowing has obscured the situation, it appears that the upper clay is recent alluvium overlying the older loamy natural levee deposits. No dark midden development was visible and no artifacts were recovered.

I later used a soil probe in an attempt to detect remnants of the sub-mound midden near the center, and on the western edge, of the mound. At the mound center, sandy loam sediments were present to a depth of at least $1.6 \mathrm{~m}$ without any distinct change indicative of a buried soil. It is possible that this probe sampled backfill from McKinney's 1959 trench. However, a similar situation also was encountered in the probe on the western edge of the mound. Despite these results, I feel that more extensive investigation of Mound 3 is warranted.

\section{Mound 4}

Mound 4 was described by Webb as a sandy area, 30-40 $\mathrm{m}$ in diameter and $30-50 \mathrm{~cm}$ high, located at the terrace edge. There has not been much change since then. The mound now is visible as a $30-40 \mathrm{~cm}$ rise with poorly defined margins. Due to plowing, it might be slightly larger than reported by Webb, particularly along the east-west axis. An auger test was placed in the remnant of Mound 4. The upper $30 \mathrm{~cm}$ of deposit was brown (7.5YR4/4) fine sandy loam with dark gray loamy patches at $25 \mathrm{~cm}$. One sherd was recovered. A slightly coarser yellowish red (5YR4/6) sandy loam was present between 30 and $65 \mathrm{~cm}$. A distinct change in the deposits was encountered at $65 \mathrm{~cm}$ where a dark reddish brown (5YR3/4) very fine sandy loam was identified. This horizon might represent the pre-mound surface deposits. Between $80 \mathrm{~cm}$ and $120 \mathrm{~cm}$ was a yellowish red (5YR5/8) fine sandy loam that became increasingly coarse and mottled to a depth of $1.8 \mathrm{~m}$. No artifacts were recovered.

\section{Mound 7}

Webb designated a circular sandy area east of Mound 4 as Mound 7. The mound does not show up well topographically, although there is a slight rise between Mound 4 and the property line, farther east than plotted by Webb. In 2004, an auger test placed in the approximate area reported by Webb did not encounter a distinct buried soil horizon or a clay overburden leaving the status of Mound 7 as a cultural feature in doubt. Numerous artifacts are present on the plowed surface in the area, however, suggesting that habitation may have taken place there. We sampled the area with four 20-x-20-m grid units that also were used for the gradiometer study (Figure 30). Surface collections also were made from each of the grid units. The greatest number of artifacts was found in the northeastern unit, which is slightly higher in elevation.

Two large anomalies were present in the gradiometer data: one around N4866/E5240 and another around N4874/E5236. Both anomalies are similar to signatures that have proven to be prehistoric archeological features at other sites, however we have not yet tested this area with excavation units.

\section{Mound 8}

Mound 8, located adjacent to the old railroad tracks south of the plaza, was not described by Webb. No distinct mound is present in the area now. The most likely location is a low sandy rise south of Mound 6 (see Figure 7). 


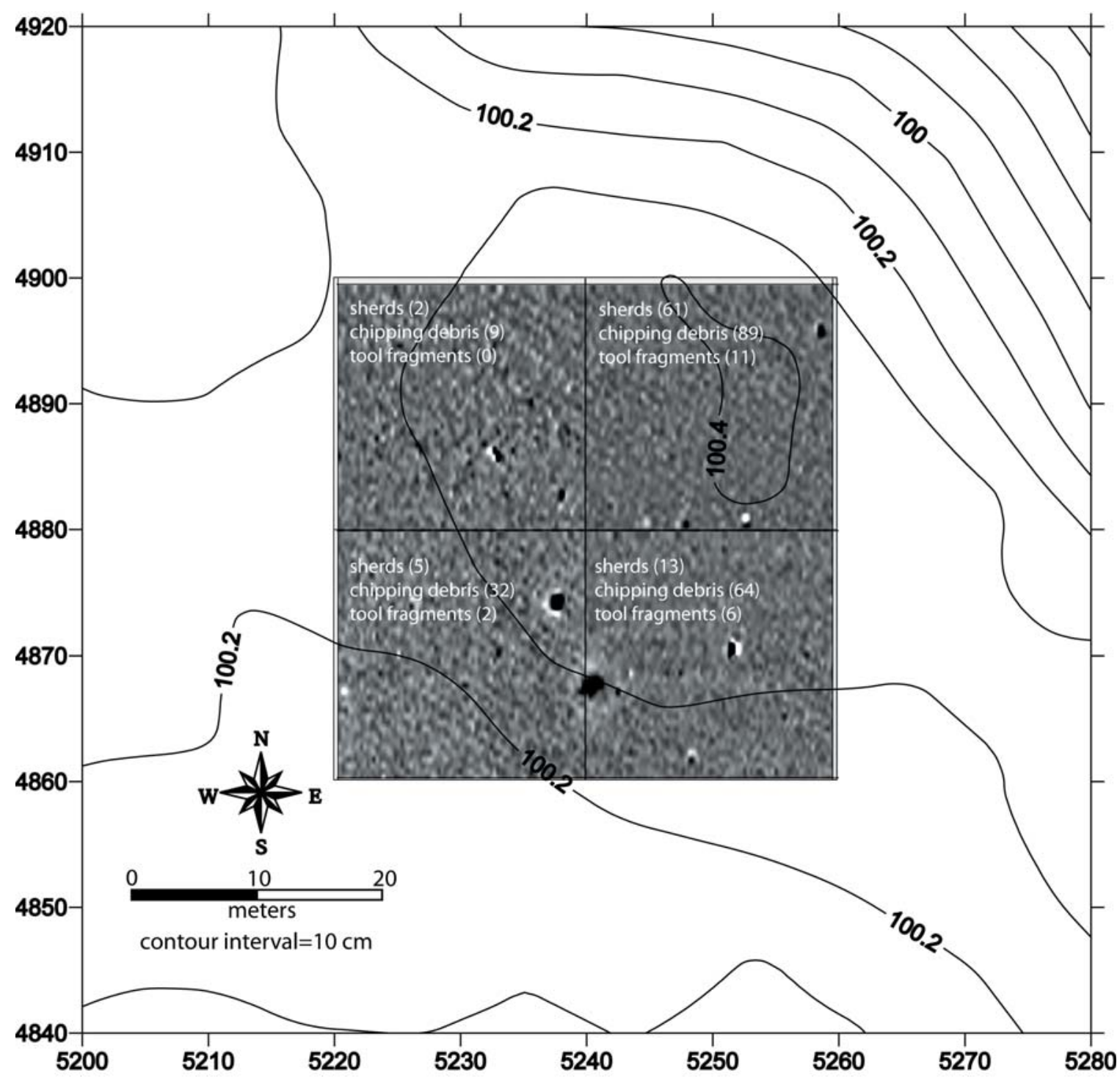

Figure 30. Sample grids in the Mound 7 area with gradiometer data.

Mound 9

The rise designated Mound 9 by Webb is readily visible as a sandy patch $35 \mathrm{~m}$ (north-south) by $25 \mathrm{~m}$ (east-west) in size located about $400 \mathrm{~m}$ northwest of Mound 2 (see Figure 4). It is less than $50 \mathrm{~cm}$ high. Webb described Mound 9 as 15 to $18 \mathrm{~m}$ in diameter. Although edges are not easily defined, it is likely that it has been spread by plowing since Webb's description.

I placed an auger test in the approximate center of the rise. The upper $20 \mathrm{~cm}$ were reddish brown (5YR4/4) very fine sandy loam. Between $20 \mathrm{~cm}$ and $30 \mathrm{~cm}$ below surface was a layer of dark reddish brown (5YR3/3) silt loam, followed by an abrupt change to yellowish red (5YR5/6) fine sandy loam. This deposit continued to $1.2 \mathrm{~m}$ below the surface at which point there was another abrupt change to dark reddish brown (5YR3/2) silt loam containing charcoal flecks. This deposit continued to at least $1.5 \mathrm{~m}$ when the deposits became saturated. The dark deposits at $1.2 \mathrm{~m}$ appear to represent a buried soil; probably the pre-mound surface. However, no artifacts were recovered in the auger test or were visible on the surface in the Mound 9 area. 


\section{Mound 10}

Webb noted that another possible mound was located immediately northwest of the plaza. This was a low rise that still had a tenant farm house on its summit in the early 1960s. When visited in 1985, the house had been removed and the presence of prehistoric artifacts led McCrocklin (1985:15) to conclude that it was another mound (Mound 10). The rise remains quite distinct and appears well defined on the topographic map (see Figure 7). An auger test was placed on the top of the rise. Much historic debris (brick fragments, bottle glass, whiteware sherds) was present on the surface. The upper $40 \mathrm{~cm}$ were the typical yellowish red (5YR4/6) very fine sandy loam. A dark reddish brown (5YR3/3) horizon that might represent a buried surface was present between 40 and $55 \mathrm{~cm}$. Slightly coarser yellowish red (5YR5/6) fine sandy loam was present beneath to a depth of at least $1.9 \mathrm{~m}$. If a mound if represented here, remaining mound deposits appear to be only about $40 \mathrm{~cm}$ thick. In 2008, a small surface collection was made from the mound surface.

\section{Summary and Conclusions}

Although Mounds Plantation has undergone substantial changes from the time when Dickeson visited in the early $19^{\text {th }}$ century, recent investigations demonstrate that additional research there is crucial for understanding the beginnings and early development of the Caddo cultural tradition. Three test pits were excavated on the southeastern flank of Mound 2 in 2007 and 2008 in order to explore anomalies detected by geophysical techniques during the 2007 Arkansas Archeological Survey project (Lockhart and Girard 2007). The test units did not reveal features that clearly relate to the anomalies detected in the geophysical data. Although it is possible that a dark area (high resistance) visible in the Test Pit 1 area relates to Feature 1, a burned posthole discovered in the southeast corner of unit N5012E4865 (units are 1-x-1-m squares designated by their southwest corner grid point), it seems equally plausible that historic debris encountered in the upper deposits is responsible for the high resistance signals. Although ambiguous with regard to the geophysical data, the information provided by excavation of the test units is of considerable interest. It was evident in all of the units that a stratum of clay has been deposited over the old natural levee surface upon which the Caddo occupation took place. Deposits that overlay the clay in Test Pits 1 and 3 were displaced from the top or slopes of Mound 2, perhaps as a result of an attempt by a former landowner to cut down the mound in the early 1960s. These deposits contained historic materials dating to the early $20^{\text {th }}$ century. In Test Pit 2 , located farther from the mound, the clay deposit is exposed on the surface.

The area sampled near Mound 2 at Mounds Plantation appears to relate to the early and middle $11^{\text {th }}$ century (Table 6) when distinctively Caddo ceramic assemblages were just beginning to develop. Of particular interest is that the recovered ceramics do not reflect late $11^{\text {th }}$ or $12^{\text {th }}$ century occupation of the Mound 2 area. Use of space in this portion of the site changed around the middle $11^{\text {th }}$ century. I suspect that this was a time of extensive mound construction, perhaps transforming Mounds Plantation from a residential site to a ceremonial center. Residential use of the area east of Mound 2 might have stopped, resulting in deposition of few or no artifacts and other debris. Ceramic data reported by Webb and McKinney (1975) from contexts underlying Mound 3, and that from beneath Mound 6 reported here support this notion. These contexts contain substantial amounts of Coles Creek Incised sherds. A far more diverse assemblage is present on the second habitation level of Mound 3, overlying the early mound deposits. Webb observed that- "It appears that heavy occupation of the submound and surrounding area occurred during Coles Creek times, that construction of the mound occurred during the Coles Creek-Alto transition, and that the mound was used only for burial placements during the later Bossier and Belcher periods" (Webb and McKinney 1975:47). Webb's "Coles Creek-Alto transition" appears to date to the middle $11^{\text {th }}$ century. It is possible that the appearance of a distinctly Early Caddo period ceramic assemblage and construction of the mound-plaza complex were contemporary, and perhaps related, events. 
Deposits relating to Mound 5 remain on the site, despite attempts to level the area and the excavations of the early 1960s. The 2006 test unit encountered a probable large burial pit beneath 40 to $50 \mathrm{~cm}$ of moundfill. The pit did not appear to cut through the mound deposits suggesting it represents one of the earliest burials in the Mound 5 area. This area might constitute a "sacred precinct" established prior to construction of Mound 5, similar to that identified by Story (1997) at the Davis Site (41CE19) in East Texas.

The test unit in Mound 6 showed that, as was the case at Mound 3 (Webb and McKinney 1975), two construction stages are present and a well-developed midden underlies at least a portion of the earthwork. The midden contains a high density of pottery with few decorated specimens. Decorations primarily consist of simple incised bands around vessel rims resembling the Greenhouse and Blakely varieties of the type Coles Creek Incised. A radiocarbon date on scattered charcoal recovered in the midden indicates a late $10^{\text {th }}$ or early $11^{\text {th }}$ century time of occupation (Table 6). No features were encountered within the midden and we can say little about the nature of the represented occupation except that it resulted in deposition of a large amount of broken pottery, a moderate amount of stone chipping debris, and a few fragments of burned bone. In contrast, Webb and McKinney (1975) reported considerable faunal remains beneath Mound 3 and speculated that it might have served as an area for food preparation during feasts.

Concentrations of artifacts along the margin of an abandoned channel segment on the northern edge of the site (McCrocklin 1985) suggest that substantial habitation occurred throughout the Early Caddo period, or until the $13^{\text {th }}$ century. More detailed information about the sequence of occupation at the site should be acquired following analysis of the extensive 1985 surface collections now in the Arkansas Archeological Survey collections.

The degree to which Mounds Plantation served as a "regional" center is not clear. Population appears to have been aggregated in the site area-very few Early Caddo period sites have been identified elsewhere in this portion of the Red River floodplain, although a few upland sites are known (e.g., Lintz et al. 2007). Mortuary data clearly indicate the presence of a social elite (Webb and McKinney 1975), but influence may have been limited to the site and a sparse outlying population.

The paucity of debris relating to the Middle Caddo period (ca. AD 1200-1500) indicates that the role of Mounds Plantation in Caddo society changed, perhaps transforming from a place of feasting, elite residence, and mortuary ceremonialism, to a sacred place where few activities were carried out that resulted in artifact deposition. However, substantial Middle Caddo period habitation debris is present along Irish Bayou approximately $1 \mathrm{~km}$ to the northwest (Girard 2007) and it is unlikely that Mounds Plantation had no significance to Middle Caddo period populations. During the $12^{\text {th }}$ century occupation began in the Willow Chute Bayou locality east of the river, forming an extensive floodplain community that lasted into the early $15^{\text {th }}$ century (Girard 2010). This community included at least three mounds, but these were widely dispersed across the landscape and no Middle or Late Caddo period multiple mound/plaza sites are present in northwest Louisiana that may have functioned as ceremonial centers to integrate multiple communities.

No burials relating to the Middle Caddo period have been found, but Late Caddo period (ca. AD 15001700) burials were placed in the upper portions of Mounds 3 and 5 at Mounds Plantation. Although the burials included several ceramic vessels, they were not obviously of social elites. Contemporary burials, some with greater amounts of burials goods, were present $10 \mathrm{~km}$ to the north at the Belcher Site (16CD13) (Webb 1959) suggesting that social ranking within communities may have continued into the Late Caddo period. 


\section{Acknowledgements}

The research that is the subject of this paper was conducted through the State of Louisiana's Regional Archaeology Program based at Northwestern State University of Louisiana. It has been financed with state funds and with federal funds from the National Park Service, U.S. Department of the Interior. I am very grateful to Mike Volentine, owner of the Mounds Plantation Site, who granted permission to carry out the investigations and also removed clay overburden and backfilled our excavations in the Mound 2 area. The Nolan family allowed us to excavate the test unit on the east side of Mound 5. Volunteers who assisted with the test units include Jameel Damlouji, Louis Baker, Mark Walters, Mike Montgomery, Joe Saunders, and Stuart Nolan. Jami Lockhart directed the geophysical survey with assistance from Michael Evans, David Jeane, and Jamie Brandon. Special thanks to Pat Boulware of the St. Louis Art Museum for providing information on Dickeson's Mississippi Panorama.

\section{References Cited}

Fowke, Gerard

1928 Archaeological Investigations-II. Forty-fourth Annual Report of the Bureau of American Ethnology, pp. 399-540. Washington, D.C.

Girard, Jeffrey S.

2005 Regional Archaeology Program, Management Unit 1: Sixteenth Annual Report. Report on file at the Louisiana Division of Archaeology, Department of Culture, Recreation, and Tourism, Baton Rouge.

2007 Regional Archaeology Program, Management Unit 1: Eighteenth Annual Report. Report on file at the Louisiana Division of Archaeology, Department of Culture, Recreation, and Tourism, Baton Rouge.

2010 Caddo Communities of North Louisiana. In The Archaeology of Louisiana, edited by M.A. Rees, pp. 195-210. Louisiana State University Press, Baton Rouge.

Jurney, David H., and Velicia Bergstrom

2001 Silica Froth: An Indicator of Thatch Architecture. Journal of Northeast Texas Archaeology 15:1-7.

Lintz, Christopher, Floyd Largent, Tim Perttula, Vincent Dongarra, Marsha Prior, and Marie Huhnke

2007 National Register Evaluative Testing at Prehistoric Site 16B0450, 16B0458, and 16B0473, Barksdale Air Force Base, Bossier Parish, Louisiana. Report submitted to United States Air Force, Air Combat Command, by Geo-Marine, Inc., Plano, Texas.

Lockhart, Jami J. and Jeffrey S. Girard

2007 Archaeogeophysical Survey at Mounds Plantation (16CD12). In Regional Archaeology Program, Management Unit 1: Eighteenth Annual Report by Jeffrey S. Girard, pp. 17-30. Report on file at the Louisiana Division of Archaeology, Department of Culture, Recreation, and Tourism, Baton Rouge.

McCrocklin, Claude

1985 An Interim Report (25March 1985) on a Surface Survey on the Mounds Plantation Site (16CD12). Arkansas Archeological Society Field Notes 210:3-5).

Moore, Clarence B.

1912 Some Aboriginal Sites on Red River. Journal of the Academy of Natural Sciences of Philadelphia, Volume 14 (Pt.4), pp. 482-640, Philadelphia. 


\section{References Cited (cont.)}

Phillips, Phillip

1970 Archaeological Survey in the Lower Yazoo Basin, Mississippi, 1949-1955. Papers of the Peabody Museum, Harvard University, Vol. 60. Cambridge

Rathbone, Perry T.

1950 Mississippi Panorama. City Art Museum of St. Louis, St. Louis.

Rodgers, Jody

2009 Montroville Wilson Dickeson Collection. University of Pennsylvania, Penn Museum Archives, Philadelphia.

Schambach, Frank F.

1998 Pre-Caddoan Cultures in the Trans-Mississippi South. Arkansas Archeological Survey Research Series 53, Fayetteville.

Story, Dee Ann

1997 1968-1970 Archeological Investigations at the George C. Davis Site, Cherokee County, Texas. Bulletin of the Texas Archeological Society 68:1-113.

Triska, Frank J.

2008 Ecology and History of the Red River Raft. In Freeman and Custis Red River Expedition of 1806: Two Hundred Years Later, edited by L.M. Hardy, pp. 307-324. Bulletin of the Museum of Life Sciences No. 14, Louisiana State University in Shreveport.

Veatch, Arthur C.

1899 The Shreveport Area. In A Preliminary Report on the Geology of Louisiana, Geological Survey of Louisiana, Special Report No. 2, pp. 152-208. Baton Rouge.

Webb, Clarence H.

1959 The Belcher Mound: A Stratified Caddoan Site in Caddo Parish, Louisiana. Society for American Archaeology Memoir 16, Salt Lake City.

1983 The Bossier Focus Revisited: Montgomery I, Werner, and other Unicomponent Sites. In Southeastern Natives and Their Pasts, edited by D. G. Wyckoff and J. L. Hofman, pp. 183-240. Studies in Oklahoma's Past No. 11. Oklahoma Archeological Survey, Norman.

2000 Stone Points and Tools of Northwestern Louisiana, Special Publication of the Louisiana Archaeological Society, Number 1 , Second Edition

Webb, Clarence H., and Ralph McKinney

1975 Mounds Plantation (16CD12), Caddo Parish, Louisiana. Louisiana Archaeology 2:39-127.

Weinstein, Richard A., David B. Kelley, and Joe W. Saunders

2003 Introduction. In The Louisiana and Arkansas Expeditions of Clarence Bloomfield Moore, edited by Richard Weinstein, David B. Kelley, and Joe W. Saunders, pp. 1-213. The University of Alabama Press, Tuscaloosa and London. 